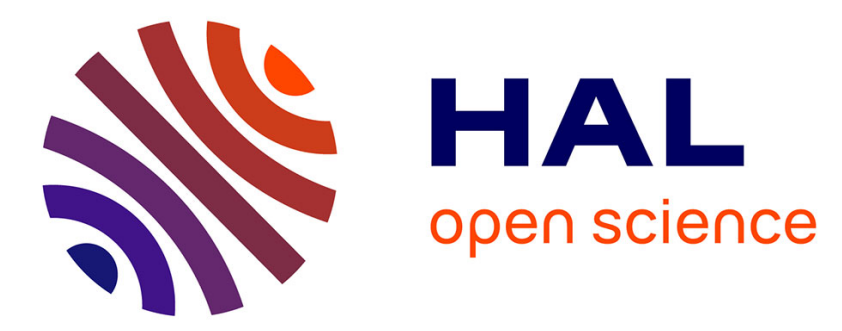

\title{
Characterization and sampling of a deep and heterogeneous aquifer -An application to the Paleocene -Eocene aquifer in the Aquitaine basin, France
} F. Gal, Jérôme Barrière, Laurent André, Arnaud Wuilleumier

\section{- To cite this version:}

F. Gal, Jérôme Barrière, Laurent André, Arnaud Wuilleumier. Characterization and sampling of a deep and heterogeneous aquifer -An application to the Paleocene -Eocene aquifer in the Aquitaine basin, France. Journal of Hydrology, 2021, 596, pp.126098. 10.1016/j.jhydrol.2021.126098 . insu03148912

\section{HAL Id: insu-03148912 \\ https://hal-insu.archives-ouvertes.fr/insu-03148912}

Submitted on 22 Feb 2021

HAL is a multi-disciplinary open access archive for the deposit and dissemination of scientific research documents, whether they are published or not. The documents may come from teaching and research institutions in France or abroad, or from public or private research centers.
L'archive ouverte pluridisciplinaire HAL, est destinée au dépôt et à la diffusion de documents scientifiques de niveau recherche, publiés ou non, émanant des établissements d'enseignement et de recherche français ou étrangers, des laboratoires publics ou privés. 


\section{Journal Pre-proofs}

Research papers

Characterization and sampling of a deep and heterogeneous aquifer - An application to the Paleocene - Eocene aquifer in the Aquitaine basin, France

F. Gal, J. Barrière, L. André, A. Wuilleumier

PII:

S0022-1694(21)00145-1

DOI: https://doi.org/10.1016/j.jhydrol.2021.126098

Reference:

HYDROL 126098

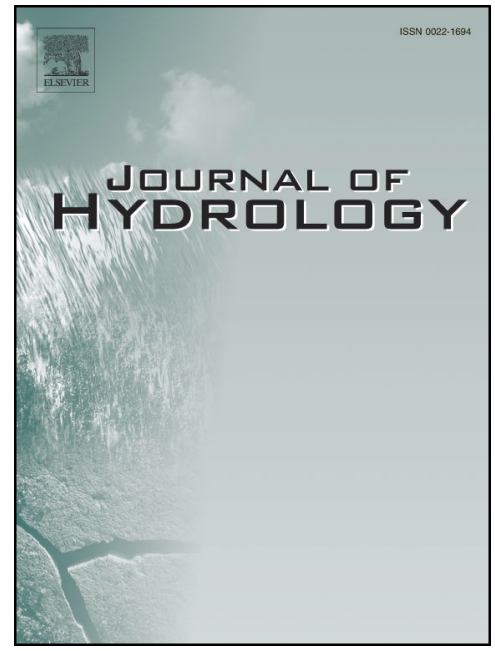

To appear in: $\quad$ Journal of Hydrology

Received Date: $\quad 20$ October 2020

Revised Date: $\quad 26$ January 2021

Accepted Date: $\quad 15$ February 2021

Please cite this article as: Gal, F., Barrière, J., André, L., Wuilleumier, A., Characterization and sampling of a deep and heterogeneous aquifer - An application to the Paleocene - Eocene aquifer in the Aquitaine basin, France, Journal of Hydrology (2021), doi: https://doi.org/10.1016/j.jhydrol.2021.126098

This is a PDF file of an article that has undergone enhancements after acceptance, such as the addition of a cover page and metadata, and formatting for readability, but it is not yet the definitive version of record. This version will undergo additional copyediting, typesetting and review before it is published in its final form, but we are providing this version to give early visibility of the article. Please note that, during the production process, errors may be discovered which could affect the content, and all legal disclaimers that apply to the journal pertain.

(C) 2021 Elsevier B.V. All rights reserved. 
1 Characterization and sampling of a deep and heterogeneous aquifer - An application to the

2 Paleocene - Eocene aquifer in the Aquitaine basin, France

3

4 Authors:

$5 \quad$ F. Gal ${ }^{1 *}$, J. Barrière ${ }^{2}$, L. André ${ }^{1,3}$, A. Wuilleumier ${ }^{2}$

6

$7 \quad 1$ : BRGM, 3 Avenue Claude Guillemin, F-45100 Orléans

$8 \quad$ 2: BRGM, 24 Avenue Léonard de Vinci, F-33600 Pessac

$9 \quad 3$ : Université d'Orléans, CNRS, BRGM, ISTO, UMR 7327, 45071 Orléans, France

$10 *$ : corresponding author: $\underline{\text { f.gal@brgm.fr }}$ 


\section{Abstract}

Groundwater sampling in boreholes has been carried out for decades according to well-established protocols and regulations. An important requirement in this context is the need to purge the borehole prior to any sampling action, the volume of the purge being adapted to the water flow and the regulatory context. Contaminated site investigations have introduced the concept of water column heterogeneity in the screened section of boreholes, which also occurs in some uncontaminated boreholes or in long-screened boreholes. Specific guidelines and practices were thus introduced, in particular the concept of discrete sampling. This type of sampling can be advantageously used in deep boreholes, provided that there is some renewal of water at the screens or the perforated intervals. The present study aims to take a step forward in the characterization of deep boreholes set up in the Aquitaine basin in France, by defining a protocol for relatively short boreholes (depth $<170 \mathrm{~m}$ ) and applying it to much deeper boreholes, formerly drilled for oil and gas exploration (sampling up to $1035 \mathrm{~m}$ deep). Acquisitions were performed to better characterize water chemistry, including some isotope considerations. They were based on physico-chemical logging and endoscopic inspections where technically possible. After a review of the information provided by the investigations on the characterization of the Paleocene - Eocene aquifer in southwestern France, a methodology is proposed to make sampling in deep boreholes with low-yield more reliable, by combining the abstraction of a reduced water volume and the use of a downhole sampling system.

\section{Keywords}

Deep borehole - downhole sampling - water sample representativeness 
Water sampling, and especially groundwater sampling in boreholes, which is the focus of this study, has been performed for decades either for regulatory purposes (water drinking regulations) or for a better knowledge of aquifers. Best practice guidelines were defined early (e.g. Rainwater and Thatcher, 1960) and have evolved regularly since then, based on feedbacks from field operators and regulators (e.g. Brown et al., 1970; Wood, 1976; Gibb et al., 1981; Lallemand-Barrès, 1993). In Europe, the focus was placed on best practices thanks to the first regulatory framework for groundwater in the end of the 1970's (Directive 80/68/EC). Subsequent directives, namely the Water Framework Directive (WFD) in 2000 (Directive 2000/60/EC) and its daughter directive on groundwater in 2006 (Directive 2006/118/EC), have completed the corpus. These directives aimed to achieve good (quantitative and chemical) status for water bodies supposedly by 2015 . As a result, a large literature is available worldwide to help in better sampling and thus characterizing groundwaters (e.g. OFEV, 2003; USGS, 2006; Duncan et al., 2007; Ministère du Développement Durable, de l'Environnement et des Parcs du Québec, 2011; Ghestem et al., 2017). Moreover, most of the guidelines are in accordance with those from the ISO standards, and more specifically the 5667 standard and its parts (ISO 5667-11, 2009).

One of the main principle exposed in these guidelines is the need of purging a borehole prior to any sampling (Barcelona and Helfrich, 1986). This is because the water in the screened section is renewed due to flow patterns but the water above the screened section is not and is therefore not representative of the groundwater (US-EPA, 1999). In most cases, the flow pattern in the screened section is lateral and directly related to that of the aquifer as a function of its transmissivity, but wellbore flow (vertical mixing) may occur especially in open holes and boreholes with long or multiple screened sections (USGS, 2006). Additionally, water sampling from boreholes that cannot produce a continuously pumped sample or boreholes in which water-level recovery takes longer than 24 hours after being pumped is not recommended (USGS, 2006). Apart from these cases, the general rule is to evacuate at least one volume of water in the well casing, and preferably three to five volumes, to get 

a representative sample (US-EPA, 1999). Depending on the flowrate of the pump, the pump intake will be located either above the screened section (high flow-rate pump) or in the screened section (low flow-rate pump) in order to avoid damaging screens and displacing the gravel-pack.

Besides these guidelines, several exceptions to the rule exist, for example on contaminated sites where volatile organic compounds may be monitored (Barcelona et al., 1994) or in open holes in fractured bedrock (Shapiro, 2002). In such cases, other pumping strategies may be required because sampling results have been demonstrated to be sensitive to well-purging rate, the volume of abstracted water and the disturbance created by downhole pumping (Gibb et al., 1981). From an assumption of homogeneity of the water column in the screened section, the view progressively shifted to the highlight of the role of heterogeneity in the water column, as in geological logs (Puls and Barcelona, 1996). This led to the development of low-flow purging techniques (Puls and Powell, 1992), which have demonstrated their usefulness in small-diameter boreholes equipped with shortscreened intervals (Barcelona et al., 1994, 2005), and to the use of inflatable packers where screened intervals are long or in open holes (Smellie and Wikberg, 1991; Shapiro, 2002). Later on, other systems for discrete sampling at low-flow have been designed: the Model 401 Waterloo Multilevel System (Solinst ${ }^{\circledR}$; Cherry and Johnson, 1982), the Continuous Multichannel Technology system (Solinst ${ }^{\circledR}$; Einarson and Cherry, 2002), the Water FLUTe ${ }^{\mathrm{TM}}$ (Flexible Liner Underground Technologies, Ltd. Co; Cherry et al., 2007) or the Westbay MP system (Westbay Instruments Inc.; Black et al., 1986). Such sampling systems are mostly used in shallow boreholes $(<100 \mathrm{~m})$ and benefit from a large number of sampling points allowing discrete and precise characterization of the water column (Chapman et al., 2015). Nevertheless, some of these systems have a far larger investigation depth (up to $1200 \mathrm{~m}$ for the Westbay system; Einarson, 2005). These systems appear to be relevant for sitespecific borehole monitoring, but they require dedicated borehole completions. In the case of preexisting boreholes, implementing such systems may turn out to be costly (i.e. if there is no need of permanent or regular monitoring of the aquifer), provided the borehole diameter is adapted (Einarson, 2005). 
When the depth of investigation has to be further extended, the use of multi-ports systems is less common, with the exception of the U-tube sampling system, a positive fluid displacement pump using a high pressure gas drive and valves, designed for Carbon Capture and Storage applications and operated through a dedicated completion (Freifeld et al., 2005). The U-tube system was deployed down to 2870 m (Conaway et al., 2016) and nested deployments allowing multi-level sampling are also reported (Boreham et al., 2011). If the sampling system has to be retrievable, sampling may rely on downhole (in-situ) sampling systems. The use of electric submersible pumps and sampling systems used in the oil industry is not considered for cost reasons (Crombie et al., 1998; WolffBoenisch and Evans, 2014). Downhole sampling systems are namely positive displacement samplers, vacuum samplers and flow-through samplers (Wolff-Boenisch and Evans, 2014). These samplers need to be driven down to the desired sampling depth with a wireline, and valve mechanisms allow fluid sampling by means of pressure differential (positive displacement and vacuum samplers) or not (flow-through sampler).

We present here the results of investigations performed on some deep boreholes of the Aquitaine Basin, in southwest France, between 2014 and 2018. The acquisitions were not all done under the same project so that focus and outcomes may differ from one well to the other. Deep sampling was always performed, to characterize the water chemistry (characterization of the gas contents is not presented here). In some cases, physico-chemical logging was performed prior the investigations, to assess the evolution of parameters along the water column in boreholes that are not used for water supply. Some pumping phases were also done in selected boreholes, to evaluate if relevant deep sampling can be performed without any well-bore purging or not. Though the data were acquired to improve the knowledge on deep aquifers in this large sedimentary basin, they are mainly used to define an approach to get reliable estimates of the chemistry of deep aquifers and therefore to set a methodological approach for further investigations in similar boreholes. 


\section{Hydrogeological settings and boreholes description}

110 The surveyed boreholes are located in the southern part of the Aquitaine basin. Two boreholes

111 (Labruguière, LBG and Valdurenque, VLD) are located close to the eastern border of the basin, and

were drilled in 1990 for water monitoring down to respectively 177 and 129 m depth (Figure 1). They

are equipped with stainless steel screened sections so the water flow is supposed to be better

constrained. The three other boreholes are old and deep wells initially drilled for oil exploration in

the second half of the XXth century (André et al., 2005). These wells were generally drilled to some

kilometers depth. They were converted later into groundwater monitoring boreholes by sealing their

lower parts and by perforating the casing at a selected depth interval (Roche, 1977). For example,

Polastron (PO-101) well was drilled in 1957 down to $2751 \mathrm{~m}$ depth and is now perforated at only

818.5-828.5 $\mathrm{m}$ depth (Figure 1), i.e. there is no more water flow from horizons deeper than $828.5 \mathrm{~m}$

Lacquy (LC-101) well is perforated at $435-445 \mathrm{~m}$ depth.
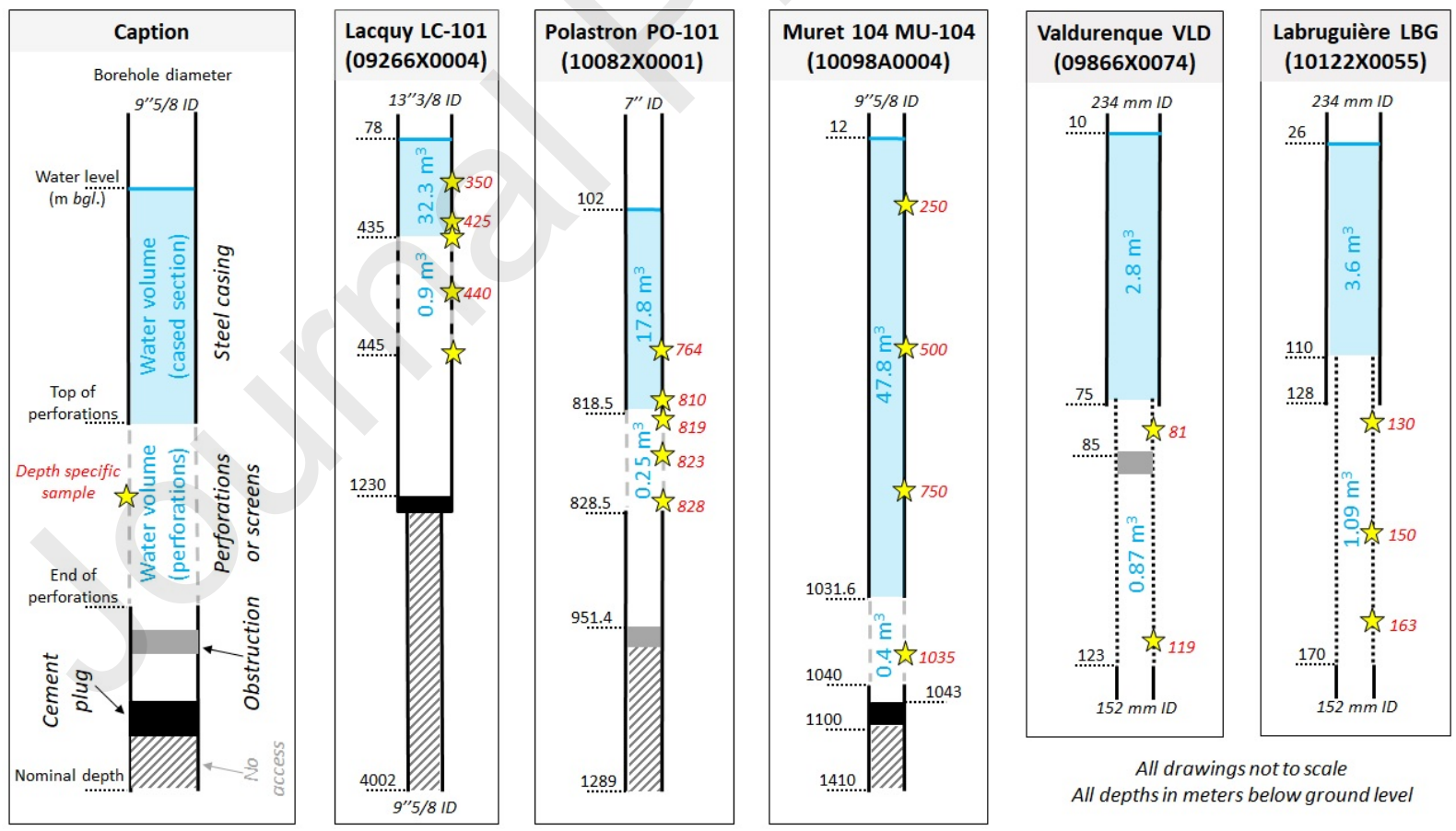

Figure 1: boreholes geometry with location of the screened sections or the perforations; the volumes indicate the depths of sampling with GOG in this study. 
In the former oil exploration wells (PO-101, MU-104 and LC-101) water flows locally through

128

129

130

131

132

perforations in the steel casing but the water flow is less constrained than in screened intervals because perforations were made using isolated explosive charges and the connectivity to the aquifer can be variable from one borehole to the other. Nevertheless, their long-term water table monitoring suggests that some hydraulic connectivity to the aquifer remains. Last, as the casing material is steel, sampling depths have to be considered with care regarding the potential influence of corrosion on water quality if water is not renewed (Pohlmann and Alduino, 1992).

The studied boreholes tap one of the major aquifer system of the Aquitaine basin, the FG082 aquifer (ADES, 2020) formed by sands, limestones and dolomites of Paleocene to Eocene age. This aquifer is one of the main water resources in the basin and is used for several applications over its wide extent: drinking water, irrigation, thermal and hydrothermal resources and gas storage in aquifer (André et al., 2002, 2005; Brenot et al., 2015). Most of this FG082 aquifer (99.3\% of its surface) is confined. This aquifer has highly variable chemical characteristics in relation with a variety of lithologies and a large range of depth (from tens of meters to several hundreds). This Paleocene to Eocene aquifer encloses indeed aquifer formations from Danian (limestone) and Selandian (sandstone and gravel sands) ages, which are tapped below $1500 \mathrm{~m}$ depth in the center of the basin, and aquifer formations from the Ypresian to Lutetian age, which are tapped by LC-101, PO-101, MU-104 and LBG at lower depths

(Figure 1). The Ypresian to Lutetian aquifer is also called the infra-molassic sand aquifer and is formed by sands and gravels with possible minor intercalations of sandy clays. Last, the VLD borehole taps slightly younger formations from the Lutetian age (so called "gravel clays").

Little information is known on the hydraulic properties of the deep boreholes tapping the Paleocene - Eocene aquifer - with the exception of water table monitoring data that are not discussed here (SIGES AQI, 2020). On the three deep boreholes, information is available for MU-104 (BSS EAU, 2020a) and to a lesser extent for PO-101 (Berard and Sourisseau, 1998). The storage coefficient of 
$151 \mathrm{MU}-104$ at c.a. $1000 \mathrm{~m}$ in the infra-molassic sands is only $1.5 \times 10^{-4}$ thus confirming the confined

152 character of the aquifer. The transmissivity $\left(1.8 \times 10^{-5} \mathrm{~m}^{2} \cdot \mathrm{s}^{-1}\right)$ and the estimated permeability (

$1531.0 \times 10^{-6} \mathrm{~m} \cdot \mathrm{s}^{-1}$ ) are low too for MU-104 borehole. The yield rate of PO-101 was not evaluated by

154 pumping during its conversion into a piezometer but by the means of swabbing that again suggested

155 a low productivity (AFBAG, 1974). The two shallower boreholes (LBG and VLD) have storage

156 coefficients of $1.0 \times 10^{-2}$, suggesting that the confined character exists even close to the recharge

157 area. The productivity is also low (transmissivities of $6.5 \times 10^{-5} \mathrm{~m}^{2} . \mathrm{s}^{-1}$ for LBG and $5.0 \times 10^{-5} \mathrm{~m}^{2} . \mathrm{s}^{-1}$

158 for VLD).

159 As for hydraulic properties, only little information is available on water quality at depth and most of

160 the available data are for equipped boreholes. Deep sampling in such boreholes is publicly reported

161 only once, together with physico-chemical characterization of the water column, but far above the

162 perforations (Négrel et al., 2008).

3. Methods

\subsection{Borehole characterization}

Because the integrity of old boreholes is poorly constrained, endoscopic (camera) inspections were completed in some boreholes (LC-101 and PO-101) prior to any other investigation, in order to check borehole integrity. This diagnostic has not been done in the shallower boreholes (LBG and VLD), because they benefit from better knowledge. Physico-chemical logging has been done in LBG and VLD (by BRGM) and in LC-101 and PO-101 (by a subcontractor, Hydro-Assistance). Physico-chemical logging has been done first under natural flow conditions and, if possible, during and/or after pumping, in order to help in locating the water inflows in the boreholes. Probes used were Idronaut 303 or 316 models equipped with pressure, temperature, electrical conductivity, $\mathrm{pH}$, redox and dissolved oxygen sensors. No endoscopic or physico-chemical logging were done in MU-104. 
177 The strategy of pumping also differed from boreholes to others. There was no pumping in MU-104.

178 Sequential pumping was performed in the shallow boreholes (LBG and VLD) using a 2 inches pump

179 (max. flow rate $<2 \mathrm{~m}^{3} \cdot \mathrm{h}^{-1}$ ). A larger pump (4 inches) was used by the subcontractor to produce water from PO-101 (flow rate: $4.3 \mathrm{~m}^{3} \cdot \mathrm{h}^{-1}$ ) and LC-101 (flow rate: $4 \mathrm{~m}^{3} \cdot \mathrm{h}^{-1}$ ).

\subsection{Deep sampling}

Deep sampling was performed using the BRGM GOG (for Gaz-O-Gaz) proprietary system (Gal et al., 2014, 2017). Like the U-tube system (Freifeld et al., 2005), the GOG sampling system is based on the use of ball check-valve operated by pressure of a neutral gas (nitrogen). The gas pressure is applied to the drive leg, and the sample is collected from a second leg, the sample leg (Figure 2). Unlike the U-tube system, the GOG system is a mobile and retrievable system, made of flexible tubing (polyamide), which can be lowered to any depth in a borehole. If the system is operated several times in a borehole, logging-like information can be obtained. This allows e.g. performing several sampling in a perforated horizon. In order to optimize the efficiency of valve functioning and to operate with reasonable gas pressure, the ball check-valve is deployed under $250 \mathrm{~m}$ of water column at maximum. The nitrogen pressure to apply to get water flowing at the surface is thus 25 bars plus some additional bars linked to pressure losses, in the range of admissible pressure of the flexible pipe (working pressure 25 bars; burst pressure 50 bars). Below the ball check-valve, a unique leg, with a ballast, is deployed down to the desired sampling depth. It acts as a straw: when deployed, it fills with water from the entire water column. A purging phase is thus needed to get water from the horizon to be sampled. In case of little depth changes from one location in the borehole to the other, the geometry of the GOG system is fixed and defined prior the investigations (Figure 2). In case of large interval between the sampling depths (MU-104), the system is retrieved at the surface, and its geometry adapted, between each use of the system. By geometry, the GOG system has an internal 
capacity of $1.25 \mathrm{~L}$ per $100 \mathrm{~m}$ of leg deployed under the water level. The total volume of water is thus

$2.5 \mathrm{~L}$ per $100 \mathrm{~m}$ between the valve and the water level. The duration of a cycle, i.e. the time between the end of one water flow and the following one, is 15 minutes; Figure 2 describes the working principle of the GOG system.
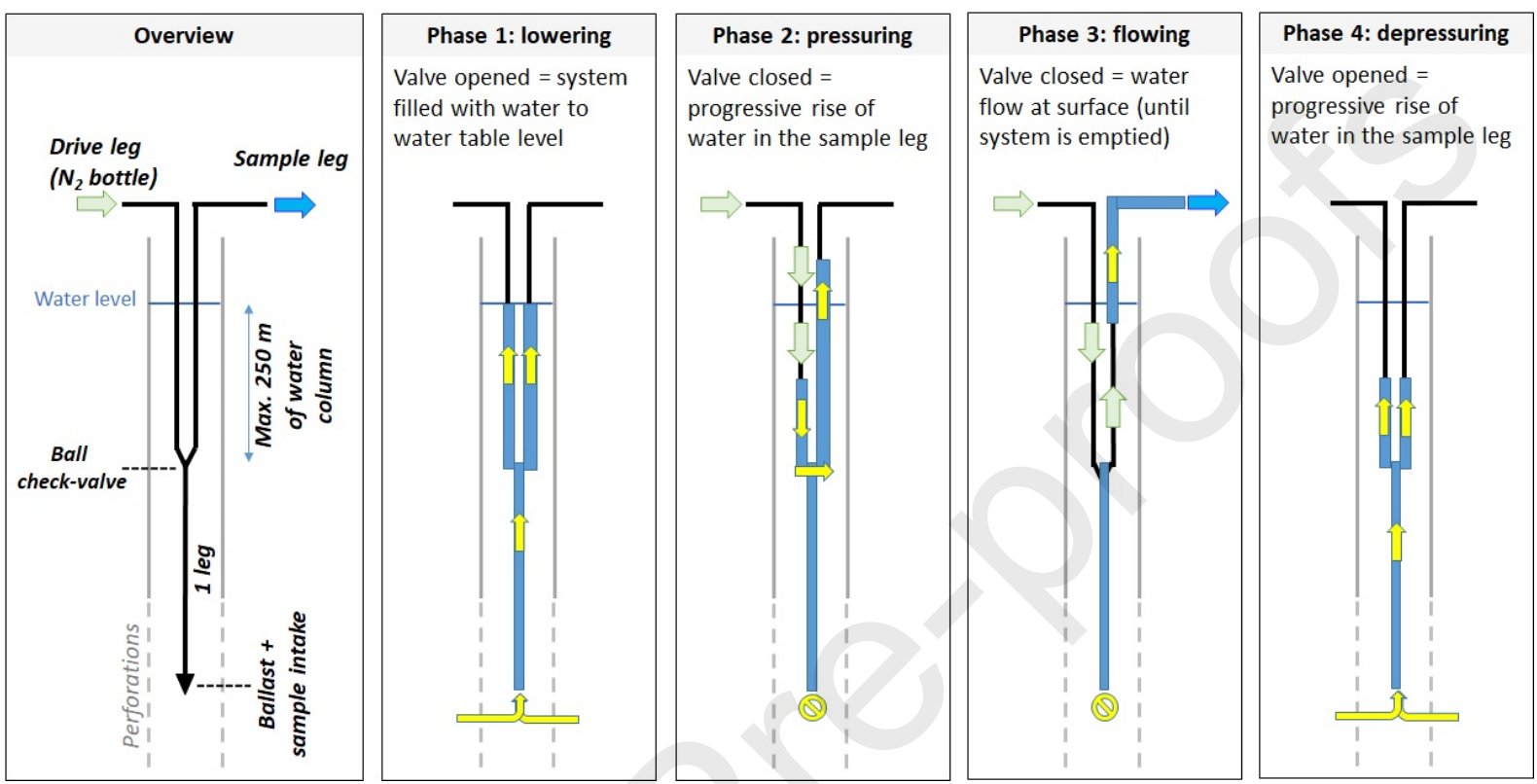

Figure 2: principle of sampling using the GOG system: from left to right: generic scheme of a GOG deployment in a borehole; working principle in four steps: 1 : lowering of the system in the borehole (valve open); 2: nitrogen pressuring (closing of the valve and initiation of fluid ascent in the sample leg); 3: fluid production from the sample leg until the drive and sample legs are emptied; 4: valve opening by pressure release (initiation of water ascent in the drive and sample legs, from the leg deployed below the valve; after completion, the system is in step 1 configuration).

\subsection{Laboratory analyses}

Major elements were analysed for LBG, VLD, LC-101, MU-104 and PO-101. Trace elements were analysed for LBG, VLD, LC-101 and PO-101. Samples were filtrated $(0.45 \mu \mathrm{m})$ on site and acidified when required. 
217 Isotopes of the water molecule $\left(\delta^{18} \mathrm{O}\right.$ and $\left.\delta \mathrm{D}\right)$ and isotope of the sulfates $\left(\delta^{18} \mathrm{O}_{\mathrm{SO} 4}\right.$ and $\left.\delta^{34} \mathrm{~S}_{\mathrm{SO} 4}\right)$ were determined for MU-104 and PO-101 (the characterization of LC-101 samples is not discussed here). Other isotope characterizations were done for LC-101 and PO-101 and are discussed by Barrière et al. (2019).

\section{Results}

\subsection{Endoscopic inspection}

Prior characterizing groundwater using depth specific sampling, it is important to get as many

information as possible about the well completion. In that perspective, endoscopic inspections were performed in LC-101 and PO-101. Camera investigations were stopped prematurely in LC-101 because an oil supernatant was observed above the water table. A skimming pumping of $4 \mathrm{~m}^{3}$ had therefore to be done.

The PO-101 borehole has been investigated down to the perforated horizon. The video record showed a casing in relatively good conditions, with minor oxidation above the water level. Some scalings are visible above the perforated section and over the perforations (818-829 $\mathrm{m})$. The borehole is obstructed at $951 \mathrm{~m}$, possibly by sediments from the above perforations.

\subsection{Pumping and physico-chemical logging}

Because it is important to assess if deep boreholes can be used for deep sampling and subsequent chemical characterization, whatever their use, some of them were investigated more in details in order to better understand their own dynamics. These investigations were done in two-steps. Step-1 characterizations enclose well logging at equilibrium conditions and deep sampling, then followed by pumping and a second deep sampling session at the levels previously monitored. This approach was used first in the shallow boreholes LBG and VLD, in order to define the best approach, and then at PO-101. For Step-2 characterizations, deep sampling is only performed after pumping (LC-101). This 

characterization.

\subsubsection{Boreholes characterized before and after pumping - shallow wells}

The results of physico-chemical logging of the shallow LBG and VLD boreholes are given in Figure 3 .

Only one logging operation was previously reported in LBG borehole (Négrel et al., 2006), but only down to $100 \mathrm{~m}$ bgl., i.e. in the cased section, so that no information exist on the physico-chemical evolution in the screened section.

Albeit the LBG and VLD boreholes are shallow, they have a specific response to pumping, directly

251

252

253 linked to their transmissivities. The LBG borehole cannot be pumped at high flow-rate. During the investigations, the maximum flow-rate was $1.1 \mathrm{~m}^{3} \cdot \mathrm{h}^{-1}$ and it induced a drawdown of $19 \mathrm{~m}$ in 3 hours. The pumping had then to be stopped to prevent dewatering of the submersible pump. The water level recovery after pumping is slow, with $+9 \mathrm{~m}$ in 3 hours. The VLD borehole was pumped at a slightly higher flow-rate $\left(2 \mathrm{~m}^{3} \cdot \mathrm{h}^{-1}\right)$ and the maximum drawdown was $8 \mathrm{~m}$ in 4 hours. The rise in water level after pumping is faster, with $+6 \mathrm{~m}$ in 15 minutes.

As earlier mentioned, the LBG and VLD boreholes were logged several times prior, during and after pumping. For each borehole, the pumping was operated over 3 days, with periods of rest. In LBG, 7.3 $\mathrm{m}^{3}$ were abstracted in 8.5 hours, representing 1.6 times the volume of the water column. In VLD, $14.6 \mathrm{~m}^{3}$ were abstracted in 9 hours, representing 3.5 times the volume of the water column. These values are in line with those recommended for getting a representative sample (e.g. US-EPA, 1999) but they were reached over a 3-days period, which underlines the very low productivity of VLD and especially LBG boreholes. As these boreholes are punctually surveyed for water quality purposes, a better understanding on the way they behave is thus important.

Under natural flow conditions (Figure 3), LBG had a linear temperature profile with an increase of $2.97^{\circ} \mathrm{C} / 100 \mathrm{~m}$, very close to the mean geothermal gradient. No thermal gradient could be seen from 
10 to $30 \mathrm{~m}$ below ground level in VLD and the measured gradient under $30 \mathrm{~m}$ was lower than at LBG

with a mean value of $2.44^{\circ} \mathrm{C} / 100 \mathrm{~m}$. This may be related to different ground conditions, the existence of shallower aquifers, which modifies the local gradient at VLD. The $\mathrm{pH}$ and redox evolution of LBG and VLD were similar, with $\mathrm{pH}$ values higher and redox values lower in the cased section, probably because of interaction with steel. The shape of electrical conductivity curves was different: there was no change between the cased section and the screened section in VLD, whereas the electrical conductivity was higher in the cased section of LBG. Again, for LBG, this argues for interaction with the casing. For VLD, it may suggest the existence of well-bore flow as may be postulated with the temperature log. Both dissolved oxygen values were close to zero in the cased section and this remained only valid in the screened section for LBG. For VLD, there was some remaining dissolved oxygen in the aquifer. The fact that oxygen did not exist in the cased section of VLD does not argue for well-bore flow.

The shape of the profiles evolved when the boreholes were pumped sequentially (Figure 3 ). The progressive renewal of water in the cased section was particularly well illustrated for LBG. The electrical conductivity, $\mathrm{pH}$ and redox profiles became vertical from bottom to top, further suggesting that the water inflow was mostly originated from the bottom part of the screened section (the last $20 \mathrm{~m})$. . From the electrical conductivity profile, it may be inferred that the renewal of 1.6 times the volume of the water column $\left(7.3 \mathrm{~m}^{3}\right)$ is the lowest admissible limit for column renewal because the conductivity at $45 \mathrm{~m}$ depth is still $5 \%$ higher than the conductivity at 150-170 m depth. Any lower abstracted volume may lead to erroneous characterization of the aquifer water, as shown by the conductivity profile obtained after the purge of $1.6 \mathrm{~m}^{3}$ (i.e. after 1.5 hours of pumping). This is a demonstration of the need to purge boreholes even if they have low water production when sampling is done by pumping.

This pumping phase is less critical for VLD borehole. Indeed, the electrical conductivity profile was already vertical prior to pumping, and the situation remains the same when pumping. The $\mathrm{pH}$, redox 
and dissolved oxygen profiles did also verticalize albeit there was a rise of the oxygen data in the

293 upper section of the casing probably related to air intrusion in the borehole. The location of the

water inflow was again in the lower part of the cased section. A closer look to the conductivity profile

and especially the temperature profile infers that the thermal profile was a step profile, horizons of

stable temperature alternating with horizons of steep gradient as indicated by the arrows on Figure
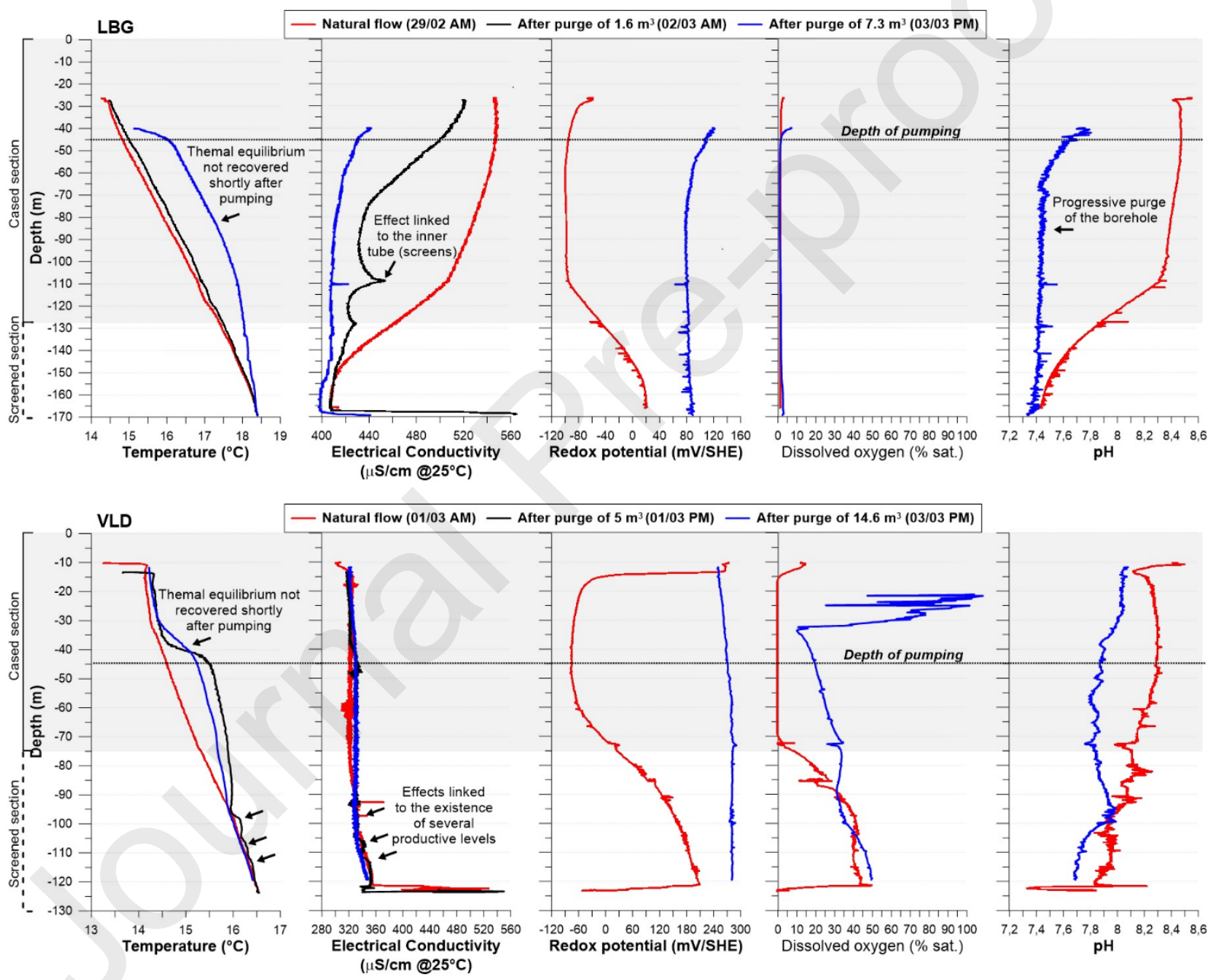

Figure 3: physico-chemical logging of LBG and VLD boreholes. Log under natural flow in red, log after pumping in blue. An intermediate logging step is plotted in black. 
304 The results of physico-chemical logging of the deep PO-101 borehole are given in Figure 4. Under

305 natural conditions, PO-101 showed a nearly vertical profile of the electrical conductivity down to 780 $\mathrm{m}$ depth with values slightly increasing from 1020 to $1170 \mu \mathrm{S} \cdot \mathrm{cm}^{-1}$ (at $25^{\circ} \mathrm{C}$ ). Correlatively the $\mathrm{pH}$ increased from 8.6 to 9.4. The redox potential was reducing, in accordance with the absence of dissolved oxygen. Such profiles characterize the interaction of a stagnant water with the steel casing. These profiles argue for the absence of casing failure as already suggested by the video inspection. Additionally, there is no developed upward migration of water from the bottom to the surface. The thermal gradient is linear, demonstrating that there is no influence of water migration outside the casing. This gradient is consistent with the mean geothermal gradient $\left(3.2^{\circ} \mathrm{C} / 100 \mathrm{~m}\right)$. The physicochemical logging demonstrates that the water inflow is originated from horizons below $780 \mathrm{~m}$ depth, likely from the perforated interval. This water inflow is particularly noticeable on the electrical conductivity data (Figure 4). Within a few meters (from 815 to $828 \mathrm{~m}$ ), the value of the electrical conductivity doubles to reach 2300 to $2400 \mu \mathrm{S} . \mathrm{cm}^{-1}$. In the meantime, the value of the $\mathrm{pH}$ decreases to 8.2. The temperature gradient is also locally perturbed in the $780-840 \mathrm{~m}$ depth interval, suggesting that some water circulates outside the casing between the Ypresian formation, the base of which is tapped by the perforations, and the underlying Paleocene aquifer and/or the overlying Lutetian formations.

Based on this log, it may be inferred that deep sampling performed without any borehole stimulation can bring water representative of the formation water in PO-101. The log performed after pumping corroborates this observation. A volume $\left(17.2 \mathrm{~m}^{3}\right)$ slightly greater than that of the water column between the pump (set at $150 \mathrm{~m}$ depth) and the perforations $\left(16.5 \mathrm{~m}^{3}\right)$ was abstracted in 4 hours (Figures 1 and 4). After pumping, the water column is entirely renewed as indicated by vertical electrical conductivity, $\mathrm{pH}$ and redox logs. The temperature log is modified by the action of pumping as warmer water is progressively drained from depth to the pump intake. All these data point to the absence of water inflows above the perforated interval. Below this interval, the physico-chemical 

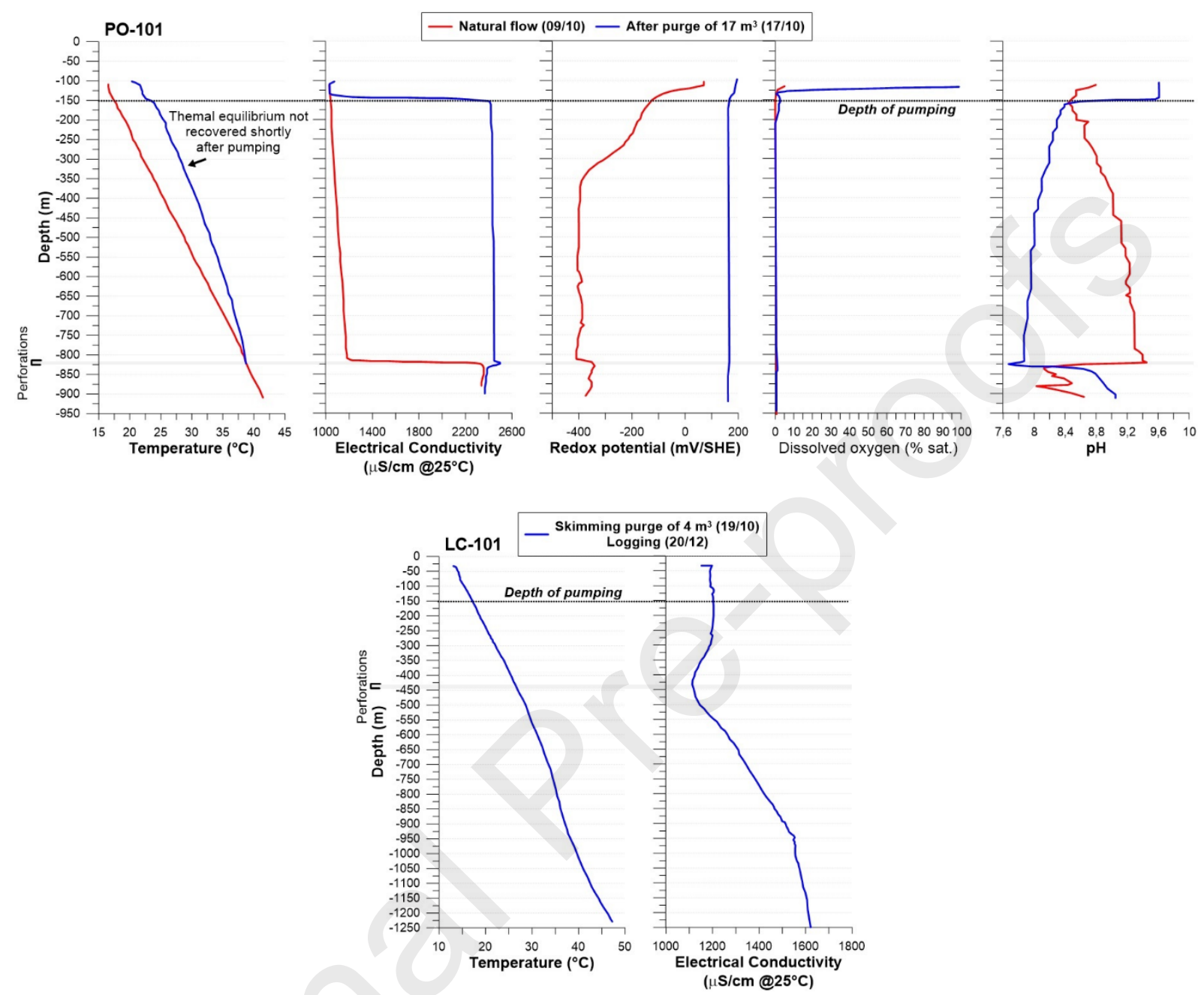

332 Figure 4: physico-chemical logging of PO-101 and LC-101 boreholes. Log under natural flow in red, log

333 after pumping in blue.

\subsubsection{Boreholes characterized only after pumping}

The LC-101 borehole was purged to skim the oil supernatant and no physico-chemical logging could

337 be done before this action. The water column was logged with a rugged device equipped with only

338 temperature and conductivity sensors two months after the skimming purge. 
Figure 4 shows the result of this logging. The temperature profile is similar to a natural profile, without pumping because the temperature gradient between the static level and $600 \mathrm{~m}$ depth is linear $\left(+3.2^{\circ} \mathrm{C} / 100 \mathrm{~m}\right)$. Between 600 and $900 \mathrm{~m}$ depth, the gradient is lower $\left(+1.9^{\circ} \mathrm{C} / 100 \mathrm{~m}\right)$ and it goes back to geothermal gradient below $\left(+3.1^{\circ} \mathrm{C} / 100 \mathrm{~m}\right.$ from 900 to $1200 \mathrm{~m}$ depth). This suggests that some water movement exists outside casing between 600 and $900 \mathrm{~m}$, but the perforated interval is supposed to be well above (430-440 m; Figure 1). At this perforated level, the electrical conductivity profile reached its lowest value (close to $1100 \mu \mathrm{S} . \mathrm{cm}^{-1}$; Figure 4). This was likely a consequence of a water inflow, which penetrates the borehole at the perforations' level. The conductivity profile above $430 \mathrm{~m}$ was smoothed compared to profiles obtained shortly after borehole purging (Figure 4) because of diffusive processes inducing the occurrence of a chemical gradient between low mineralized waters (from the perforations) and more mineralized waters (in the cased section). Below $440 \mathrm{~m}$, the conductivity progressively increased up to $1600 \mu \mathrm{S} . \mathrm{cm}^{-1}$ around $900 \mathrm{~m}$ depth, depth from where the conductivity value varies little. Such a profile does not argue for the existence of other inflows at depth.

\subsection{Water chemistry}

Major elements and trace elements analyses are given in supplementary information for depth discrete samples and for samples obtained by pumping (LBG and VLD boreholes). Chemical balance of the analyses is between $-3 \%$ and $+1 \%$.

\subsubsection{Quality of the depth specific samples}

An assessment of the representativeness of the samples acquired during the deep sampling operations, and therefore a way to get a quality control on these depth specific samples, is given in Figure 6. This figure compares, for the LBG borehole and for some parameters and dissolved elements concentrations, the results obtained using the GOG system and the results obtained using the classical pumping approach (pump set at $45 \mathrm{~m}$ depth; Figure 1). The first two discrete samples at 
130 and $163 \mathrm{~m}$ depth were taken without any wellbore purging with a circulation of respectively $10 \mathrm{~L}$ and $30 \mathrm{~L}$ of water in the system prior to sampling. The electrical conductivity therefore represents the conductivity existing at 130 and $160 \mathrm{~m}$ depth under natural flow conditions (Figure 3). When some wellbore purging is done, the water column homogenizes in the screened section and subsequent depth specific samples have minor variability in conductivity and dissolved elements (Figure 5). Depth specific samples are thus representative of the chemistry of their respective depths at the time they were taken. In the present case, this may suggest that the $130 \mathrm{~m}$ depth horizon has a higher conductivity and is slightly more enriched in $\mathrm{K}$ than the $160 \mathrm{~m}$ depth horizon. These differences disappear after the first purge of $1.6 \mathrm{~m}^{3}$ confirming that the $130 \mathrm{~m}$ depth horizon is not representative of most of the water from the aquifer. Secondly, there is minor variability of the depth discrete samples taken when some water is abstracted from the borehole, indicating that there is no contamination by the sampling system. This is illustrated by the major and trace concentrations measured at $160 \mathrm{~m}$ depth, which are invariant for all the samples whatever their time of collection, before or after purging.

As expected, the representativeness of samples obtained by pumping is much longer to obtain. The abstraction of large volumes of water is required first to purge the volume of water between the pump and the top of the screens in the cased section. This purge operates like the movement of a piston, with renewed water gradually moving upward from the screened section to the cased section. Consequently, the purge of more than $4 \mathrm{~m}^{3}$ is required to get water samples that have a similar composition than that obtained by discrete sampling at depth (Figure 5). For some trace elements, even the purge of more than one water column volume is not sufficient to achieve representativeness, as illustrated by $\mathrm{Sr}$ and especially $\mathrm{Mn}$ concentrations. For these two elements, depth discrete sampling gives more precise information, perhaps indicating the existence of some heterogeneities in the aquifer to which pumping actions are blind. 

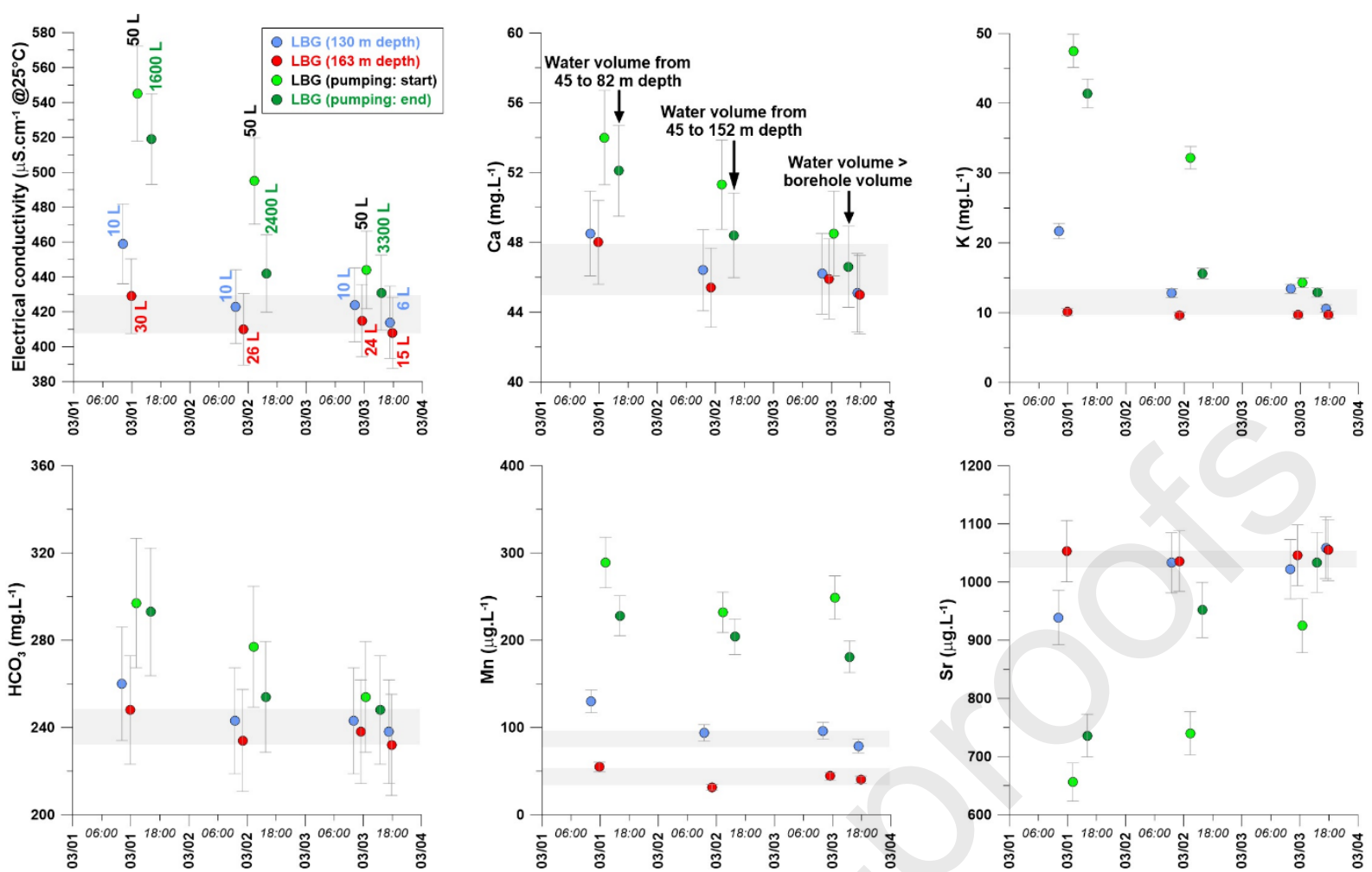

Figure 5: comparison of electrical conductivity, $\mathrm{Ca}, \mathrm{K}, \mathrm{HCO}_{3}, \mathrm{Mn}$ and $\mathrm{Sr}$ concentrations acquired

during discrete sampling and during pumping (LBG borehole). The volumes reported for depth

specific samples correspond to the volume of water purged at the depth of sampling prior sampling

action. The volumes reported for pumping correspond to sampling shortly after pump start and to

sampling after some $\mathrm{m}^{3}$ were purged. The grey fields show the variability of the data for the depth

specific samples (the first sample taken at $130 \mathrm{~m}$ depth is excluded - see text for explanations).

\subsubsection{Water chemistry}

397

There is a clear connection between the depth of the screened section or the perforated interval and the mineralization of the fluid (Supplementary information). The shallowest borehole (VLD) has the lowest mineralization (Total Dissolved Solids equivalent to $280 \mathrm{mg} \cdot \mathrm{L}^{-1}$ ) and the deepest one (MU-104) the highest (TDS of $2920 \mathrm{mg} \cdot \mathrm{L}^{-1}$ ). Two groups can be identified: low concentrated waters (TDS $<420$ mg. $\mathrm{L}^{-1}$ ), with dominant $\mathrm{Ca}-\mathrm{Mg}$ and $\mathrm{HCO}_{3}$, and more mineralized waters (TDS $>630 \mathrm{mg} \cdot \mathrm{L}^{-1}$ ), with dominant $\mathrm{Ca}$ and $\mathrm{Cl}-\mathrm{SO}_{4}$. Only the VLD samples have measurable, but low, $\mathrm{NO}_{3}$ amounts, indicating that nitrate has not been completely reduced. This is in agreement with the slightly oxidant character 
of the water. The overall trend is an increase in mineralization with depth, which is a classical trend in groundwaters in large sedimentary basins, mineralization being generally associated to longer residence time and more interaction with the aquifer matrix.

Also, a connection can be seen between the depth of the water inflow and the content in trace elements and especially elements sensitive to water-rock interaction processes. The content in $\mathrm{Sr}$ increases from $770 \mu \mathrm{g} \cdot \mathrm{L}^{-1}$ at VLD to $3700 \mathrm{mg} \cdot \mathrm{L}^{-1}$ at MU-104. Salinity indicators such as $\mathrm{B}$ or $\mathrm{Br}$ (when measured) follow the same trend. Conversely, higher concentrations in Li can be seen in LBG, greater than in MU-104 (306 and $234 \mu \mathrm{g} \cdot \mathrm{L}^{-1}$ respectively), suggesting an interaction with Li-rich rock matrix in relatively shallow environment.

\subsection{Isotopes}

Some isotope measurements were done on the samples collected in the deep boreholes (Supplementary information). Sulfur and oxygen isotopes of the dissolved sulfates and hydrogen and oxygen isotopes of the water molecule were analyzed for MU-104 and PO-101. Sampling was performed before and after pumping in PO-101 in order to determine if some variations occur when the borehole is partially purged. The values are the same before and after pumping, suggesting that direct deep sampling at the perforated depths can provide representative information at least for these isotopes.

The samples performed at several depths in MU-104 provide further information about representativeness along the water column, especially at depths far from the perforated interval. There is almost no change along the water column for oxygen and hydrogen isotopes of the water molecule considering the uncertainty on the measurement. At the opposite, there is significant variation for the sulfates, especially for the sulfur isotopes and to a lesser extent for the oxygen isotopes. When the sampling is performed at the level of the perforations (1035 $\mathrm{m})$, the volume of 
water purged during deep sampling seems to have no influence on the result and this result probably reflects the real value of sulfur isotopes in the aquifer.

\section{Discussion}

\subsection{Certainties and uncertainties in the characterization of the Paleocene-Eocene aquifer}

The goal is not to get an in-depth description of the water-rock interactions processes but rather to determine to what extent the new acquired data can be included in existing databases and if they put light on new findings.

Data from VLD borehole match the ideal expectations for the functioning of a borehole (Figure 6; Supplementary information). There is minor difference from one sample to the other whatever the monitoring approach and the depth of sampling. The data are in good agreement with those reported just after the borehole was completed (BSS EAU, 2020b). Provided the sampling material is in good condition and some water renewal is allowed prior to sampling, investigations in such a borehole are likely to bring representative samples when using a pump. A similar observation can be made if the water is sampled using a deep sampling system provided it is deployed in the screened interval. The best fit between deep sampling and pumping is obtained after one purging session (one water column volume), suggesting that some enhanced water production may be needed to renew the water column at depth. 


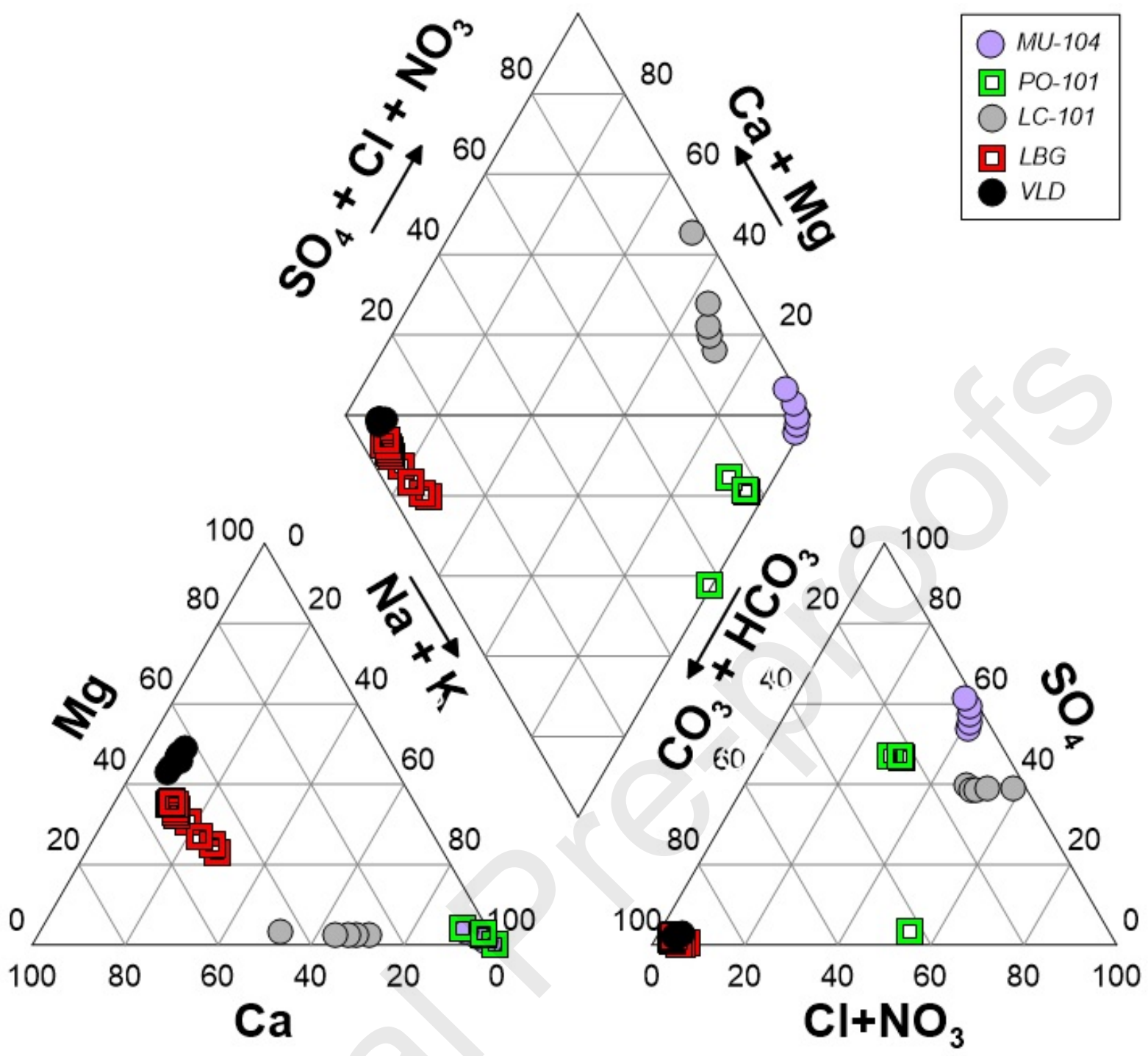

446 447

448

449

450

451

452

453

454

455

456

Figure 6: Piper diagram of all the waters sampled in the Paleocene-Eocene aquifer (depth discrete samples and samples by pumping).

Albeit being located close to VLD, the LBG borehole has a more complex functioning as illustrated by Figures 5 and 6 (and Supplementary information). Contrary to what is observed for VLD, all the new data differ from the data reported shortly after borehole completion in 1990 (BSS EAU, 2020c) and from the data reported by Brenot et al. (2015). The data acquired after completion may be unrepresentative of the chemistry of the aquifer if the borehole development has not been fully achieved in relation with the low water production. The water analysis reported in 2015 is surprisingly enriched in $\mathrm{Cl}$ and $\mathrm{SO}_{4}$ and depleted in $\mathrm{Mg}$ and no obvious explanation can be suggested. 
This sample was taken in 2006 (Négrel et al., 2006), and at this time borehole logging was done only down to $100 \mathrm{~m}$ below ground level, so the complete renewal of the water column could not be checked. If the pumping was too short to renew the whole water column, then part of the discrepancy may be related to changes in water chemistry resulting from interactions with the casing. Indeed, a similar enrichment in $\mathrm{K}$ or $\mathrm{Cl}$ was measured in the first sample taken while in the LBG borehole (Figure 5), but no $\mathrm{Mg}$ depletion or $\mathrm{SO}_{4}$ enrichments can be seen. While purging, the water chemistry progressively shifts to more and more reproducible values.

The comparison with deep sampling is informative as such. Some differences can be seen between the first two downhole samples at 130 and $163 \mathrm{~m}$ depth, and only the last one appears to be representative of the chemistry obtained at the end of well pumping (Figure 5). This confirms that the water inflow in LBG borehole occurs mostly from the bottom of the screened interval, as earlier demonstrated by physico-chemical logging. As the purge increases, the water at $130 \mathrm{~m}$ depth is progressively renewed by the upward flow, leading to a convergence of chemical data at the end of the sampling session. At that time, all the water in the screened interval has been completely renewed and even higher up to the pump intake.

As a consequence, downhole sampling, if performed in the screened interval and where water flows in, can bring interpretable data even if performed without preliminary water abstraction.

Nevertheless, some pumping actions may be operated as a quality insurance approach, in order to ensure that some water production has occurred at depth.

A good representativeness of water samples can thus be obtained when the deep sampling system is driven in the appropriate sections of boreholes. Conversely, sampling in inappropriate depth leads to erroneous characterizations, as demonstrated in Figure 7 with MU-104 samples. The first sampling, done at $250 \mathrm{~m}$ depth, has a chemical composition similar to that of the analysis reported by Brenot et al. (2015) at a similar depth. If this demonstrates some reproducibility in the sampling actions over years, this does not mean that this $250 \mathrm{~m}$ depth sample is representative of the chemistry of the 
Eocene aquifer. This is clearly illustrated by the chemical composition of deeper samples $(500,750$ and $1035 \mathrm{~m}$ ). There is a progressive enrichment, along the casing, in $\mathrm{Mg}$ and $\mathrm{Ca}$, and to a lesser extent in $\mathrm{SO}_{4}$ (path $\mathrm{A}$ in Figure 7), and conversely a progressive depletion in alkalinity and a pH decrease (Supplementary material). The same pattern can be observed in time while increasing the volume of water abstracted using the GOG system at the perforations depth (path B in Figure 7), without reaching the 1965 data, obtained when the borehole was converted into a piezometer. This 1965 sample reveals a high mineralization of the water (about $3.6 \mathrm{~g} / \mathrm{L}$ ), clearly higher than the water sampled in the same geologic formation in neighbor wells (about $0.5 \mathrm{~g} / \mathrm{L}$ - Vandenberghe, 1966). According to the author, the sample is not representative of the formation water because of the many cleaning operations after perforating. High amounts of hydrochloric acid $(\mathrm{HCl})$ and ammonium hydrogen fluoride $\left(\mathrm{F}_{2} \mathrm{H} \mathrm{NH}_{4}\right)$ acid were injected in 1965 and only half of these amounts were pumped back. The consequence was the measurement of high concentrations of chloride $(572 \mathrm{mg} / \mathrm{L})$ and fluoride $(17 \mathrm{mg} / \mathrm{L})$ which are still observable today at the bottom of the well. Assuming that the 1965 data were not representative of the aquifer chemistry at the time of collection, then the new data confirm that the contamination (by chloride and fluoride) is still present 50 years later. This reveals an insufficient water renewal at depth through the perforations and a too low purged volume (about 60 liters) from the $1035 \mathrm{~m}$ depth.

Nevertheless, even if the representativeness of the $1035 \mathrm{~m}$ depth samples may be questioned, the behavior of dissolved species at $1035 \mathrm{~m}$ and in the water column can be discussed. First, the Ca content at $1035 \mathrm{~m}$ depth is consistent with a water in equilibrium at $45^{\circ} \mathrm{C}$ with calcite and a $\mathrm{pCO}_{2}$ close to $10^{-3.5} \mathrm{~atm}$ (according to calculations with PHREEQC code - Parkhurst and Appelo, 2013). Then, the alkalinity increase in the cased section (path C in Figure 7) is probably due to two chemical processes occurring in the water column: i) corrosion of the casing, involving a $\mathrm{pH}$ increase and a decrease of Mg, Ca and Mn concentrations (Nilsson and Sandberg, 2017); and ii) sulfate reduction by micro-organisms as revealed by sulfate isotopes (see following paragraph). The sulfate reduction involves the production of sulfides (about $1 \mathrm{mmol} / \mathrm{L}$ under $\mathrm{HS}^{-}$form because of $\mathrm{pH}$ conditions) 
508

509

510

511 not indicating developed precipitation.
512

513

514

increasing the alkalinity of waters and the decrease of their redox potential. The sulfate reduction seems to be the main process impacting sulfate since the precipitation of $\mathrm{SO}_{4}$-rich phases (anhydrite, gypsum) is not supported by calculation of saturation indexes, which are always negative and thus

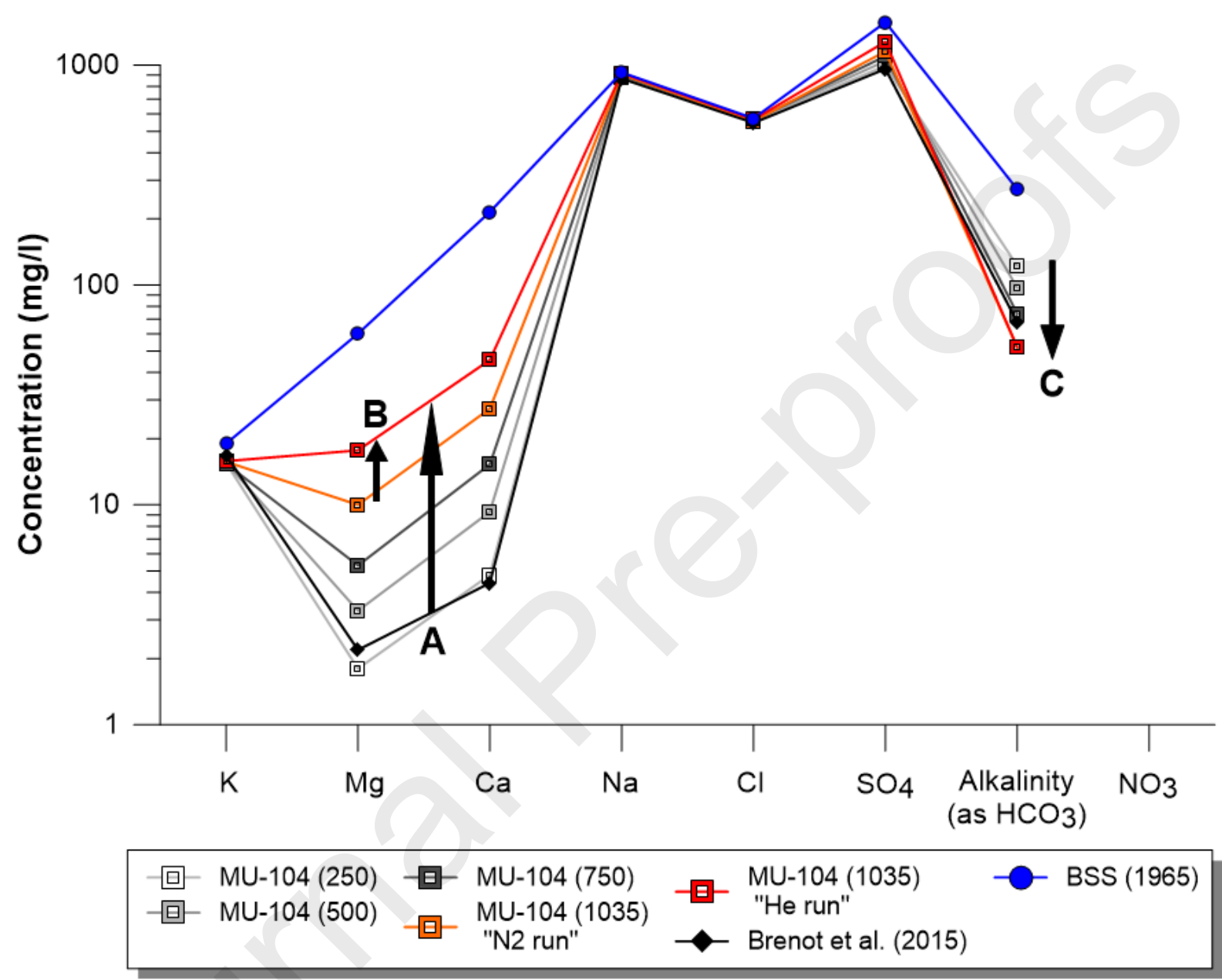

Figure 7: Schoeller diagram for MU-104 samples; note that the alkalinity is expressed as the $\mathrm{HCO}_{3}$ content; some contributing species may not have been quantified.

Another process can decrease the concentration in sulfate. Figure 8 reports the evolution of $\mathrm{S}$ and $\mathrm{O}$ isotopes of the $\mathrm{SO}_{4}$ for $\mathrm{MU}-104$ and $\mathrm{PO}-101$. There is no change of isotope signature for $\mathrm{PO}-101$ when comparing samples acquired before and after water abstraction by pumping. This suggests that water flow through perforations at depth is sufficiently developed in PO-101 and that representative 
samples can be obtained after a minor purge. The two samples obtained at $1035 \mathrm{~m}$ in MU-104 also

521 have very comparable isotope values albeit their concentrations in $\mathrm{SO}_{4}$ are slightly different. When

522 including the samples obtained in the cased section, the S-isotope ratios still point to an origin of the

523 sulfates related to interactions with evaporitic formations, as earlier reported by André et al. (2002)

524 and Brenot et al. (2015). But their plot with the O-isotope values of the $\mathrm{SO}_{4}$ (black arrow in the right

525 inset of Figure 8) leans from high ratios to lower ones, as a function of depth. The information

526 obtained at the level of the perforations is very close to the endmember representing the interaction

527 with local evaporites. In their 2015 paper, Brenot et al. reported a value obtained with a sampling at

$528250 \mathrm{~m}$ and they suggested that such a sampling may not be representative. This non-

529 representativeness is clearly established here with the new results. There is no need to refer to

530 mixing between endmembers to attribute the origin of sulfates in MU-104. This origin is the same as

531 for many other boreholes tapping the Eocene aquifer but, depending on the sampling depth, sulfate-

532 reduction processes occur in the casing and strongly alter the isotope signature of the sulfates. 

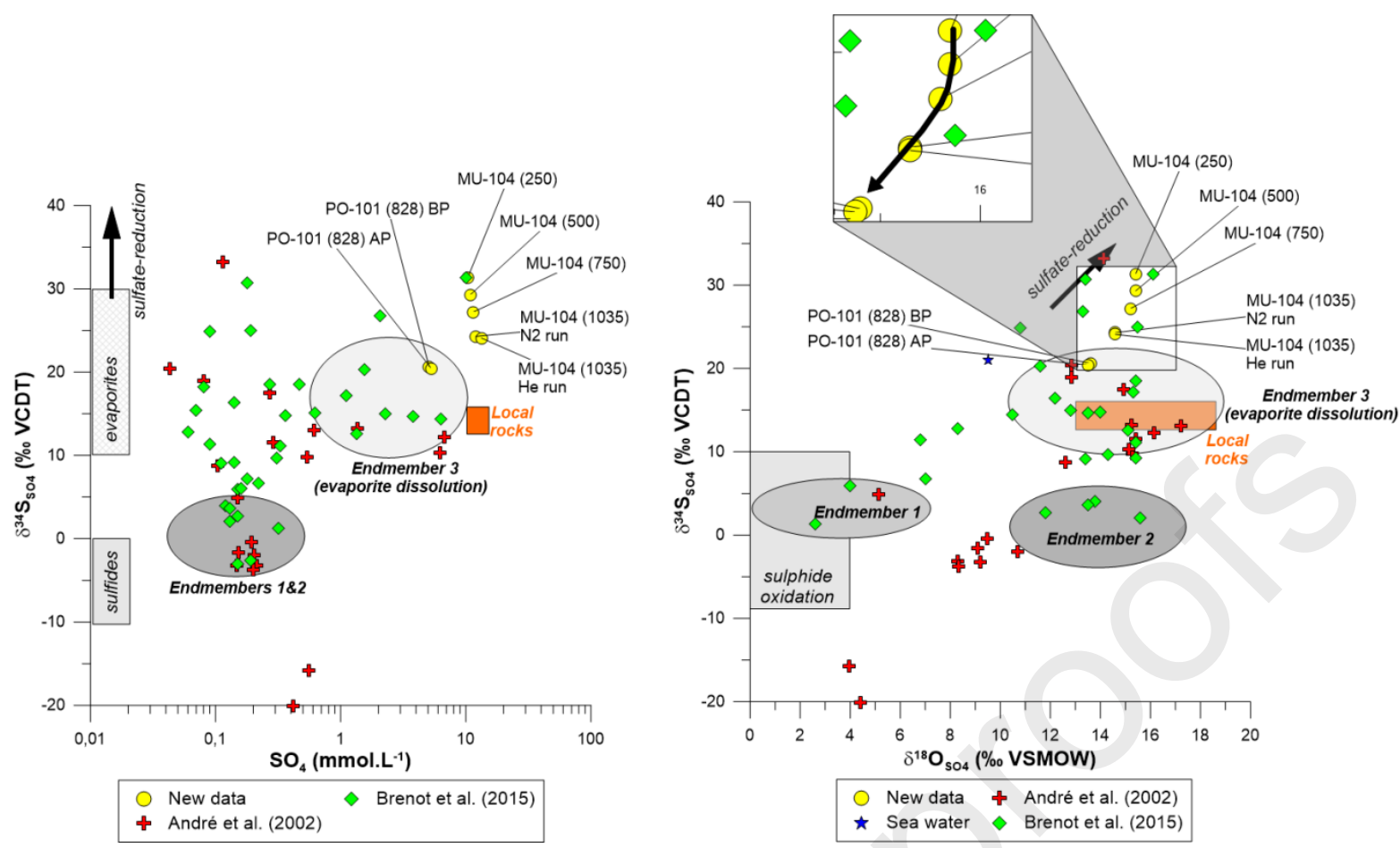

Figure 8: left: $\mathrm{SO}_{4}-\delta^{34} \mathrm{~S}_{\mathrm{SO} 4}$ relation; right: $\delta^{18} \mathrm{O}_{\mathrm{SO} 4}-\delta^{34} \mathrm{~S}_{\mathrm{SO}}$ relation. Endmembers 1, 2, 3, and local rock fields as defined by Brenot et al. (2015).

It is interesting to mention that not all the isotope ratios are modified by a long contact period with steel casing. An example can be found in Supplementary information with the oxygen and hydrogen isotopes of the water molecule. All the samples collected in the water column of MU-104 point to the same isotope value, minor variation being linked to the uncertainty on the measurement. The data obtained at $250 \mathrm{~m}$ depth give thus reliable indication on the recharge processes experienced by the MU-104 waters. The samples from PO-101 follow the same rule, with minor variations when sampled before or after borehole pumping.

547 The first outcome is for relatively shallow boreholes (LBG and VLD - tapped sections located from around 100 to $160 \mathrm{~m} \mathrm{bgl).} \mathrm{In} \mathrm{such} \mathrm{boreholes,} \mathrm{downhole} \mathrm{sampling} \mathrm{can} \mathrm{be} \mathrm{performed} \mathrm{with} \mathrm{a} \mathrm{high} \mathrm{level}$ 
549

550

551

552

553

554

555

556

557

558

559

560

561

562

563

564

565

566

567

568

569

570

571

572

of confidence provided the completion of the borehole is known and the levels of water flow in the

screened interval are located. In the absence of good knowledge of waters flows and the evolution of the borehole equipment, some water abstraction may be required to ensure water renewal in the screened section.

The second outcome is for deep boreholes and it splits into several subgroups. When the water flow is supposed to be not too low, as in PO-101, deep sampling can be operated without water abstraction. The situation becomes then similar to that of shallow boreholes. Because knowing if water flows are not too low, if the screens are not scaled or if the completion is not damaged is often tricky, complementary actions may be required before sampling downhole to ensure of representativeness of the sampling action. The first is to perform water abstraction to ensure some water renewal. This may provide information on continued existence of connectivity with the aquifer by following the water level over time but this does not provide information on the levels from which water is produced. This information can be obtained by flow logging in a borehole but also from deep sampling operations. Deep sampling performed in the perforations/screens prior to pumping and repeated when the pumping is active, with potentially displacement of the sample intake of the system, helps to locate where there is some water renewal at depth and therefore where there is connectivity to the aquifer. Because these operations may be time consuming, the use of alternative information sources, such as water logging and/or video inspection, may be preferred, but, in turn, such investigations may become costly. As a result, there is often a lack of knowledge of the functioning of deep boreholes, which is regrettable from a representativeness point of view. This may result in biased understanding of the aquifer chemical properties and reporting of nonrepresentative data.

In spite of this lack of characterization of the water flows in deep boreholes, the present study has demonstrated that the combined used of deep sampling techniques and preliminary abstraction of a 
573 water volume equivalent to that of the screened section/perforated interval may be sufficient to get

574 realistic description of the water-mass.

575

576

577

578

579

580

581

582

583

584

585

586

587

588

589

590

591

592

593

594

595

596

597

\section{Conclusions}

Deep sampling techniques were used to characterize the Eocene aquifer in the Aquitaine basin. The observed boreholes ranged from 130 to more than $1000 \mathrm{~m}$ in depth thus excluding, or making the use of a pump complex and costly. A monitoring strategy has been defined by performing sequential pumping and frequent water logging in the shallower boreholes. This suggested that deep sampling can be done with virtually no purge provided the borehole geometry is known and the productive levels are located. Because this may not be the case, a better approach is to perform some water abstraction to renew the water at the productive level(s) before doing deep sampling.

Complementary investigations such as video inspection and water logging give a better constraining of the sampling actions.

This strategy has been applied to selected deep boreholes. Albeit they were not all characterized in the same way, investigations have demonstrated that:

- Good reproducibility can be obtained by deep sampling when water flow is not too low, even without a purging step;

- In low-yield boreholes, some preliminary water abstraction may be required in view of getting samples that are more representative. An alternative approach is to have a purge-like phase with several uses of the deep sampling system prior getting samples for subsequent laboratory analyses;

- If the water is sampled from the cased section, or correlatively if the purging phase (not associated with deep sampling) is not sufficiently developed to produce renewed water at the surface, then the characterization of the aquifer chemistry can be biased: loss or gain of elements or shift in isotope signatures; 
598 The recommended approach to use for deep borehole characterization is to abstract a volume of

599 water equivalent to that of the screened interval or, if unrealistic, to activate/enhance water

600 circulation in the screened interval by abstracting several hundreds of liters of water. Some water

601 will be produced by the productive levels, even the low-yield ones, and appropriate deepening of the

602 sampling system in these levels will allow getting representative samples.

603

604 Acknowledgments

605 The BRGM Research Directorate funded acquisitions in MU-104. The GAIA project funded the

606 acquisitions in VLD, LBG, LC-101 and PO-101; Teréga, the Adour-Garonne Water Agency (AEAG) and

607 the BRGM funded the GAIA project. P. Marchet (AEAG) and P. Chiquet (Teréga) are specifically

608 thanked. Hydro-Assistance performed water logging and pumping in PO-101 and LC-101. G.

609 Bentivegna, M. Brach, E. Decouchon, M. Djemil and A. Grandemange are warmly thanked for their

610 assistance during field acquisitions. We thank the two anonymous reviewers for critical reading and

611 whose comments/suggestions helped to improve the manuscript. 
ADES, 2020. https://ades.eaufrance.fr/fmasseseau/2009/FRFG082.pdf

614

615

616

AFBAG (Agence Financière de Bassin Adour-Garonne), 1974. Transformation du forage pétrolier Polastron 101 en piézomètre de la nappe infra-molassique.

http://ficheinfoterre.brgm.fr/InfoterreFiche/scan?name=S276670.PDF\&path=/filer/scans/bss a

André, L., 2002. Contribution de la géochimie à la connaissance des écoulements souterrains profonds Application à l'aquifère des Sables Infra-Molassiques du Bassin Aquitain, PhD thesis, Bordeaux 3 University, http://sigesaqi.brgm.fr/IMG/pdf/these andre2002.pdf.

André, L., Franceschi, M., Pouchan, P., Atteia, O., 2002. Origine et évolution du soufre au sein de l'aquifère des Sables infra-molassiques du Bassin aquitain. Comptes Rendus Geoscience 334, 749756. https://doi.org/10.1016/S1631-0713(02)01814-X.

André, L., Franceschi, M., Pouchan, P., Atteia, O., 2005. Using geochemical data and modelling to enhance the understanding of groundwater flow in a regional deep aquifer, Aquitaine Basin, southwest of France. Journal of Hydrology 305, 40-62. https://doi.org/10.1016/j.jhydrol.2004.08.027. Barcelona, M.J., Helfrich, J.A., 1986. Well construction and purging effects on ground-water samples. Environ. Sci. Technol. 20, 1179-1184. https://doi.org/10.1021/es00153a015.

Barcelona, M.J., Wehrraann, H.A., Varljen, M.D., 1994. Reproducible Well-Purging Procedures and VOC Stabilization Criteria for Ground-Water Sampling. Groundwater 32, 12-22.

https://doi.org/10.1111/j.1745-6584.1994.tb00605.x.

Barcelona, M.J., Varljen, M.D., Puls, R.W., Kaminski, D., 2005. Ground water purging and sampling methods: History vs. hysteria. Groundwater Monitoring \& Remediation 25, 52-62.

https://doi.org/10.1111/i.1745-6592.2005.0001.x.

Barrière J., Gal F., André L., Wuilleumier A., with the collaboration of Bentivegna G., Djemil M., 2019.

Projet GAIA. Investigations dans les forages profonds de Polastron, Saint-André et Lacquy: 
caractérisation, diagraphies de production, prélèvements sélectifs et analyses. BRGM report RP-

Berard, P., Sourisseau, B., 1998. Ressources thermales du Bas Adour. Actualisation et régularisation

650 district, SW France): Contributions of $\delta 34 \mathrm{~S}$ and $\delta 180$ from dissolved sulfates and the $87 \mathrm{Sr} / 86 \mathrm{Sr}$ ratio.

Book 5, Chapter A1. https://pubs.usgs.gov/twri/05a01-1979/report.pdf. 
658

659

660

661

662

663

664

665

666

667

668

669

670

671

672

673

674

675

676

677

678

679

680

Chapman, S., Parker, B., Cherry, J., Munn, J., Malenica, A., Ingleton, R., Jiang, Y., Padusenko, G.,

Piersol, J., 2015. Hybrid Multilevel System for Monitoring Groundwater Flow and Agricultural Impacts

in Fractured Sedimentary Bedrock. Groundwater Monitoring \& Remediation 35, 55-67.

https://doi.org/10.1111/gwmr.12084.

Cherry, J.A., Johnson, P.E., 1982. A multilevel device for monitoring in fractured rock. Groundwater Monitoring \& Remediation 2, 41-44. https://doi.org/10.1111/j.1745-6592.1982.tb00839.x.

Cherry, J.A., Parker, B.L., Keller, C., 2007. A New Depth-Discrete Multilevel Monitoring Approach for Fractured Rock. Groundwater Monitoring \& Remediation 27, 57-70. https://doi.org/10.1111/j.1745$\underline{6592.2007 .00137 . x}$.

Conaway, C.H., Thordsen, J.J., Manning, M.A., Cook, P.J., Trautz, R.C., Thomas, B., Kharaka, Y.K., 2016. Comparison of geochemical data obtained using four brine sampling methods at the SECARB Phase III Anthropogenic Test CO2 injection site, Citronelle Oil Field, Alabama. International Journal of Coal Geology 162, 85-95. https://doi.org/10.1016/j.coal.2016.06.001.

Crombie, A., Halford, F., Hashem, M., McNeil, R., Melbourne, G., Mullins, O.C., 1998. Innovations in Wireline Fluid Sampling. Oilfield Review 26-41.

Duncan, D., Harvey, F., Walker, M., and the Australian Water Quality Centre, 2007. EPA Guidelines:

Regulatory monitoring and testing - Water and wastewater sampling.

https://www.epa.sa.gov.au/files/8494 guide wws.pdf.

Einarson, M.D., Cherry, J.A., 2002. A New Multilevel Ground Water Monitoring System Using

Multichannel Tubing. Groundwater Monitoring \& Remediation 22, 52-65.

https://doi.org/10.1111/i.1745-6592.2002.tb00771.x.

Einarson, M.D., 2005. Multilevel Ground-Water Monitoring, in: Practical Handbook of Environmental Site Characterization and Ground-Water Monitoring. Taylor and Francis, pp. 808-845. 
681

682

683

684

685

686

687

688

689

690

691

692

693

694

695

696

697

698

699

700

701

702

703

Freifeld, B.M., Trautz, R.C., Kharaka, Y.K., Phelps, T.J., Myer, L.R., Hovorka, S.D., Collins, D.J., 2005.

The U-tube: A novel system for acquiring borehole fluid samples from a deep geologic $\mathrm{CO} 2$

sequestration experiment. Journal of Geophysical Research: Solid Earth 110.

https://doi.org/10.1029/2005JB003735.

Gal, F., Brach, M., Pauwels, H., 2014. A new sampling method for collecting fluids at depth, Fourth EAGE CO2 Geological Storage Workshop, Stavanger, 22-24 April 2014.

https://www.researchgate.net/publication/266637769 A New Sampling Method for Collecting FI uids at Depth.

Gal, F., Lions, J., Grellier, S., Squarcioni, P., Barrière, J., 2017. Deep Aquifer Sampling and the Use of Ball Check-valves Systems. Energy Procedia 114, 3812-3823.

https://doi.org/10.1016/j.egypro.2017.03.1512.

Ghestem, J.P., Gal, F., Moreau, P., 2017. AQUAREF -Opérations d'échantillonnage d'eau souterraine dans le cadre des programmes de surveillance DCE-Recommandations techniques - Edition 2017. https://www.aquaref.fr/system/files/AQUAREF 2017 Guide Echantillonnage ESO.pdf.

Gibb, J.P., Schuller, R.M., Griffin, R.A., 1981. Procedures for the collection of representative water quality data from monitoring wells. Illinois State Water Survey, Illinois State Geological Survey. http://citeseerx.ist.psu.edu/viewdoc/download?doi=10.1.1.880.9682\&rep=rep1\&type=pdf.

ISO 5667-11, 2009. Water quality - Sampling - Part 11: Guidance on sampling of groundwaters. https://www.iso.org/standard/42990.html.

Lallemand-Barrès, A., 1993. Guide pratique d'échantillonnage des eaux souterraines. BRGM report R37390-ENV-4S-93 (in French). http://infoterre.brgm.fr/rapports/RR-37390-FR.pdf.

Ministère du Développement Durable, de l'Environnement et des Parcs du Québec, 2011. Guide d'échantillonnage à des fins d'analyses environnementales : cahier 3 - Échantillonnage des eaux 
souterraines, Centre d'expertise en analyse environnementale du Québec, 60 p.

http://www.ceaeq.gouv.qc.ca/documents/publications/echantillonnage/eaux soutC3.pdf.

Négrel, Ph., Colin, A., Petelet-Giraud, E., Brenot, A., Millot, R., Roy, S., 2006. CARISMEAU:

caractérisation isotopique et géochimique des masses d'eau dans le bassin Adour Garonne:

interconnections et hétérogénéités. BRGM report RP-55069-FR (in French), 128 p.

http://infoterre.brgm.fr/rapports//RP-55069-FR.pdf.

Négrel, P., Roy, S., Petelet-Giraud, E., Brenot, A., Millot, R., Dutartre, P., Fournier, I., 2008. Les outils de diagraphie chimique pour la caractérisation des masses d'eau. Principes et exemple d'application. Techniques Sciences Méthodes 11, 29-46. https://doi.org/10.1051/tsm/200811029.

Nilsson A.-C., Sandberg B., 2017. Elevated pH values in groundwater. Observations from SKB investigations 1976-2014 and possible causes. Report SKB R-16-04. ISSN 1402-3091.

http://www.skb.com/publication/2485482/R-16-04.pdf.

OFEV, 2003. Echantillonnage des eaux souterraines. Office fédéral de l'environnement, Bern.

https://www.bafu.admin.ch/bafu/fr/home/themes/eaux/publications/publications$\underline{\text { eaux/echantillonnage-des-eaux-souterraines.html. }}$

Parkhurst, D.L., Appelo, C.A.J., 2013. Description of input and examples for PHREEQC version 3 - A computer program for speciation, batch-reaction, one-dimensional transport, and inverse geochemical calculations: U.S. Geological Survey Techniques and Methods. Book 6, chap. A43, 497 p.

Pohlmann, K.F., Alduino, A.J., 1992. Potential sources of error in ground-water sampling at hazardous waste sites. Ground water issue (No. EPA/540/S-2/019). US-EPA.

\section{https://nepis.epa.gov/Exe/ZyPURL.cgi?Dockey=910004RS.txt.}

Puls, R.W., Powell, R.M., 1992. Acquisition of Representative Ground Water Quality Samples for Metals. Groundwater Monitoring \& Remediation 12, 167-176. https://doi.org/10.1111/j.1745- 
Puls, R.W., Barcelona, M.J., 1996. Low-Flow (Minimal Drawdown) Ground Water Sampling

Procedures (No. EPA/540/S-95/504), Ground Water Issue. U.S. EPA.

https://cfpub.epa.gov/si/si public record report.cfm?Lab=NRMRL\&dirEntryld=126106.

Rainwater, F.H., Thatcher, L.L., 1960. Methods for collection and analysis of water samples.

Washington, U.S. Govt. Print. Off. https://pubs.usgs.gov/wsp/1454/report.pdf.

Roche, J., with the participation of Grech, B., 1977. Surveillance piézométrique des nappes profondes dans la région Midi-Pyrénées. BRGM report 77-SGN-396-MPY (in French).

http://infoterre.brgm.fr/rapports/77-SGN-396-MPY.pdf.

Shapiro, A.M., 2002. Cautions and Suggestions for Geochemical Sampling in Fractured Rock.

Groundwater Monitoring \& Remediation 22, 151-164. https://doi.org/10.1111/j.17456592.2002.tb00764.x.

SIGES AQI, 2020. http://sigesaqi.brgm.fr/IMG/pdf/334c-sim.pdf

Smellie, J.A.T., Wikberg, P., 1991. Hydrochemical investigations at Finnsjön, Sweden. Journal of Hydrology 126, 129-158. https://doi.org/10.1016/0022-1694(91)90203-T.

US-EPA, 1999, Compendium of ERT groundwater sampling procedures. Office of Emergency and Remedial Response, U.S. Environmental Protection Agency, Washington DC.

https://www.epa.gov/sites/production/files/2015-06/documents/fieldsamp-ertsops.pdf.

USGS, 2006. Collection of water samples. In National Field Manual for the Collection of Water-Quality Data. U.S. Geological Survey Techniques of Water-Resources Investigations, Book 9, Chapter A4, Version 2.0. https://pubs.er.usgs.gov/publication/twri09A4.

Vandenberghe A., 1966. La nappe sous-molassique aux environs de Muret (Haute-Garonne). Résultat des travaux effectués sur le forage Mu 104. BRGM Report DSGR.66.A38 (in French).

http://infoterre.brgm.fr/rapports/66-DSGR-A-038.pdf. 
Wolff-Boenisch, D., Evans, K., 2014. Review of available fluid sampling tools and sample recovery techniques for groundwater and unconventional geothermal research as well as carbon storage in deep sedimentary aquifers. Journal of Hydrology 513, 68-80.

https://doi.org/10.1016/i.jhydrol.2014.03.032.

Wood, W.W., 1976. Guidelines for collection and field analysis of ground-water samples for selected unstable constituents. USGS-TWRI Book 1, Chapter D2. https://pubs.usgs.gov/twri/twri1-

\section{d2/pdf/twri 1-D2 a.pdf.}

Groundwater sampling in boreholes has been carried out for decades according to well-established protocols and regulations. An important requirement in this context is the need to purge the borehole prior to any sampling action, the volume of the purge being adapted to the water flow and the regulatory context. Contaminated site investigations have introduced the concept of water column heterogeneity in the screened section of boreholes, which also occurs in some uncontaminated boreholes or in long-screened boreholes. Specific guidelines and practices were thus introduced, in particular the concept of discrete sampling. This type of sampling can be advantageously used in deep boreholes, provided that there is some renewal of water at the screens or the perforated intervals. The present study aims to take a step forward in the characterization of deep boreholes set up in the Aquitaine basin in France, by defining a protocol for relatively short boreholes (depth $<170 \mathrm{~m}$ ) and applying it to much deeper boreholes, formerly drilled for oil and gas exploration (sampling up to $1035 \mathrm{~m}$ deep). Acquisitions were performed to better characterize water chemistry, including some isotope considerations. They were based on physico-chemical logging and endoscopic inspections where technically possible. After a review of the information provided by the investigations on the characterization of the Paleocene - Eocene aquifer in southwestern France, a methodology is proposed to make sampling in deep boreholes with low-yield more reliable, by combining the abstraction of a reduced water volume and the use of a downhole sampling system. 
776 F. Gal: Conceptualization; Methodology; Investigation; Data Curation; Writing - Original Draft;

777 Visualization; Funding acquisition

778

779

780

781

782

783

784

785

786

787

788

789

790

Highlights:

A. Wuilleumier: Conceptualization; Writing - Review \& Editing; Project administration; Funding acquisition; Supervision

- Obtaining representative samples in deep aquifers of low-yield

- Discrete sampling at great depth using a ball check-valve operated system

- Proposition of a methodology to increase representativeness of deep sampling
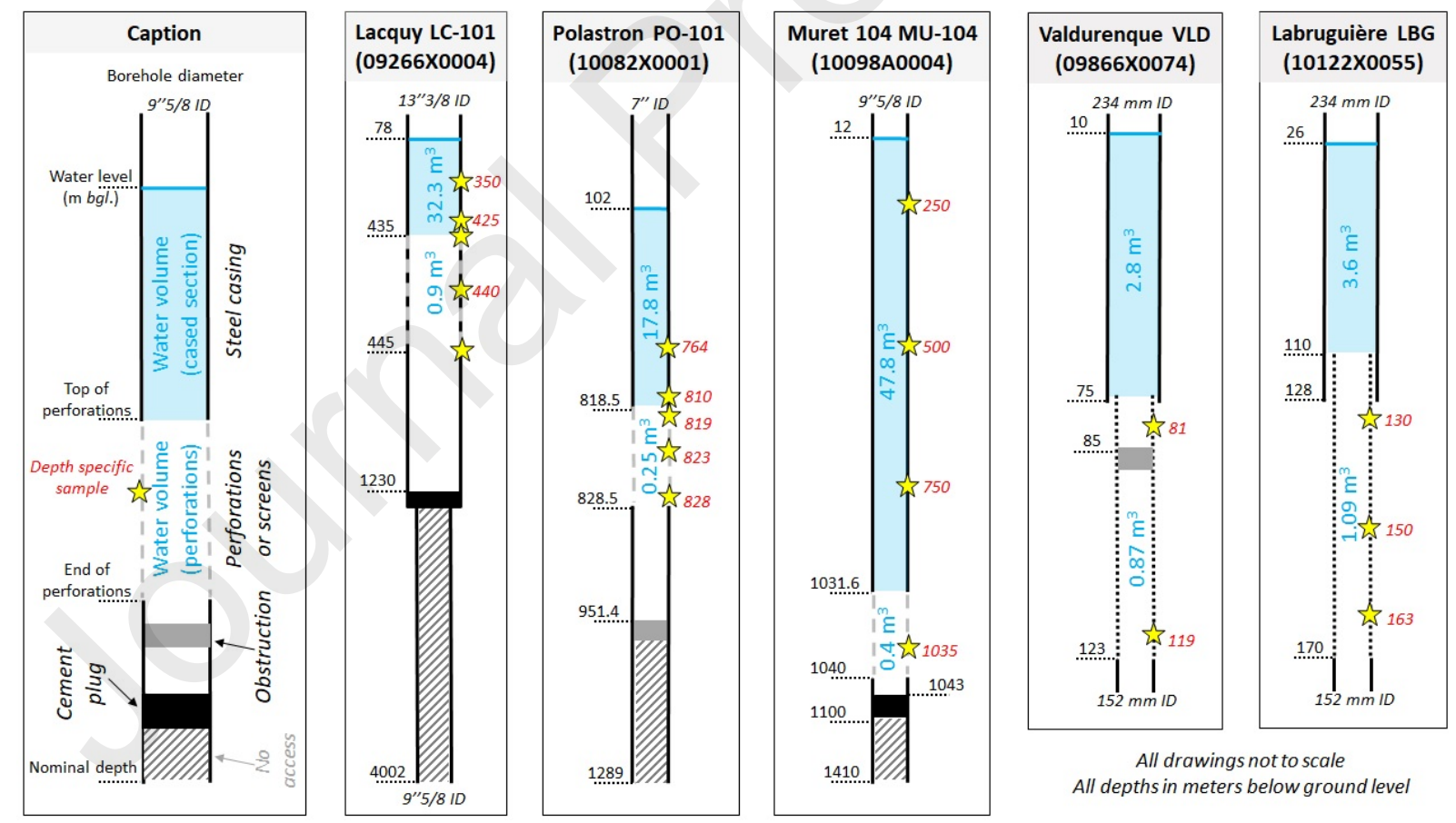

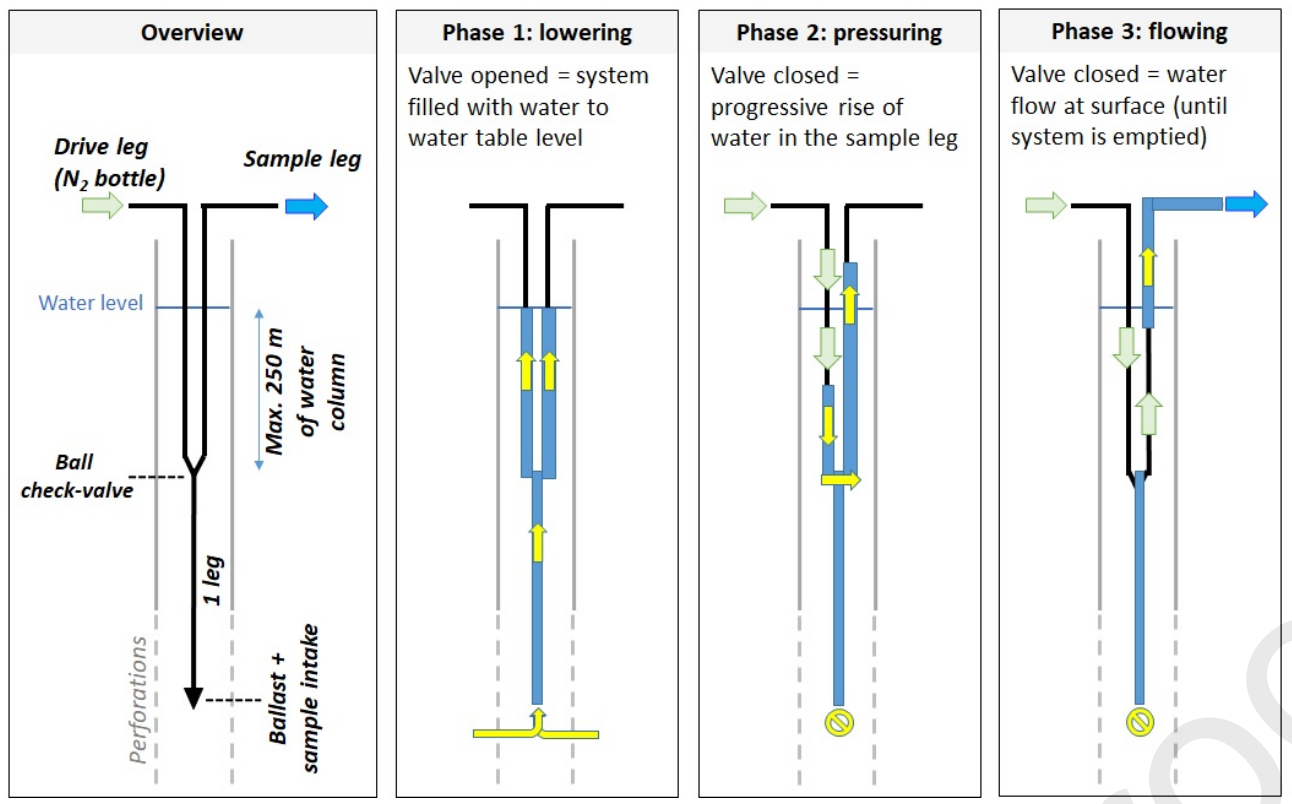

Phase 4: depressuring

Valve opened $=$

progressive rise of

water in the sample leg
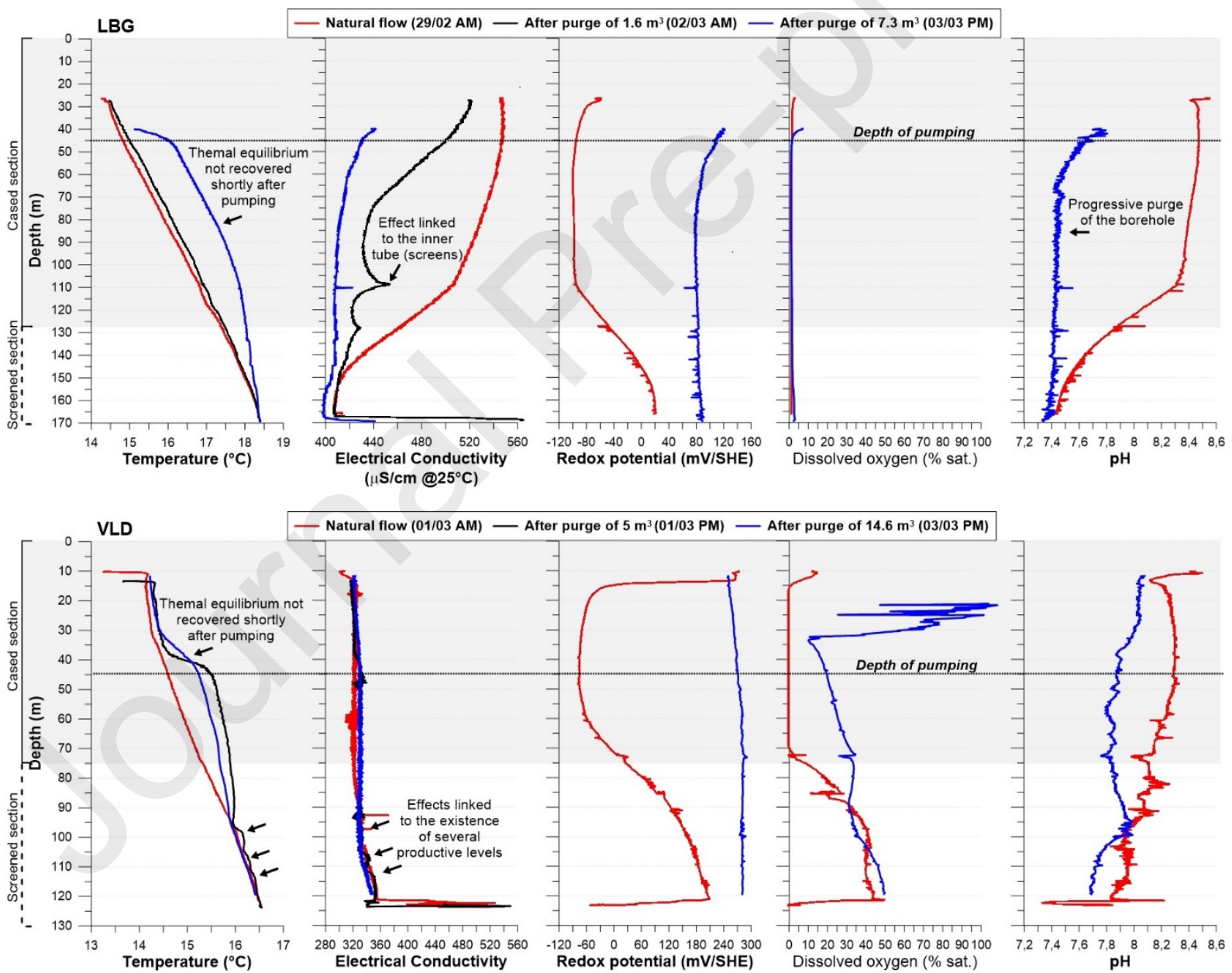
$\left(\mu \mathrm{S} / \mathrm{cm} @ 25^{\circ} \mathrm{C}\right)$ 

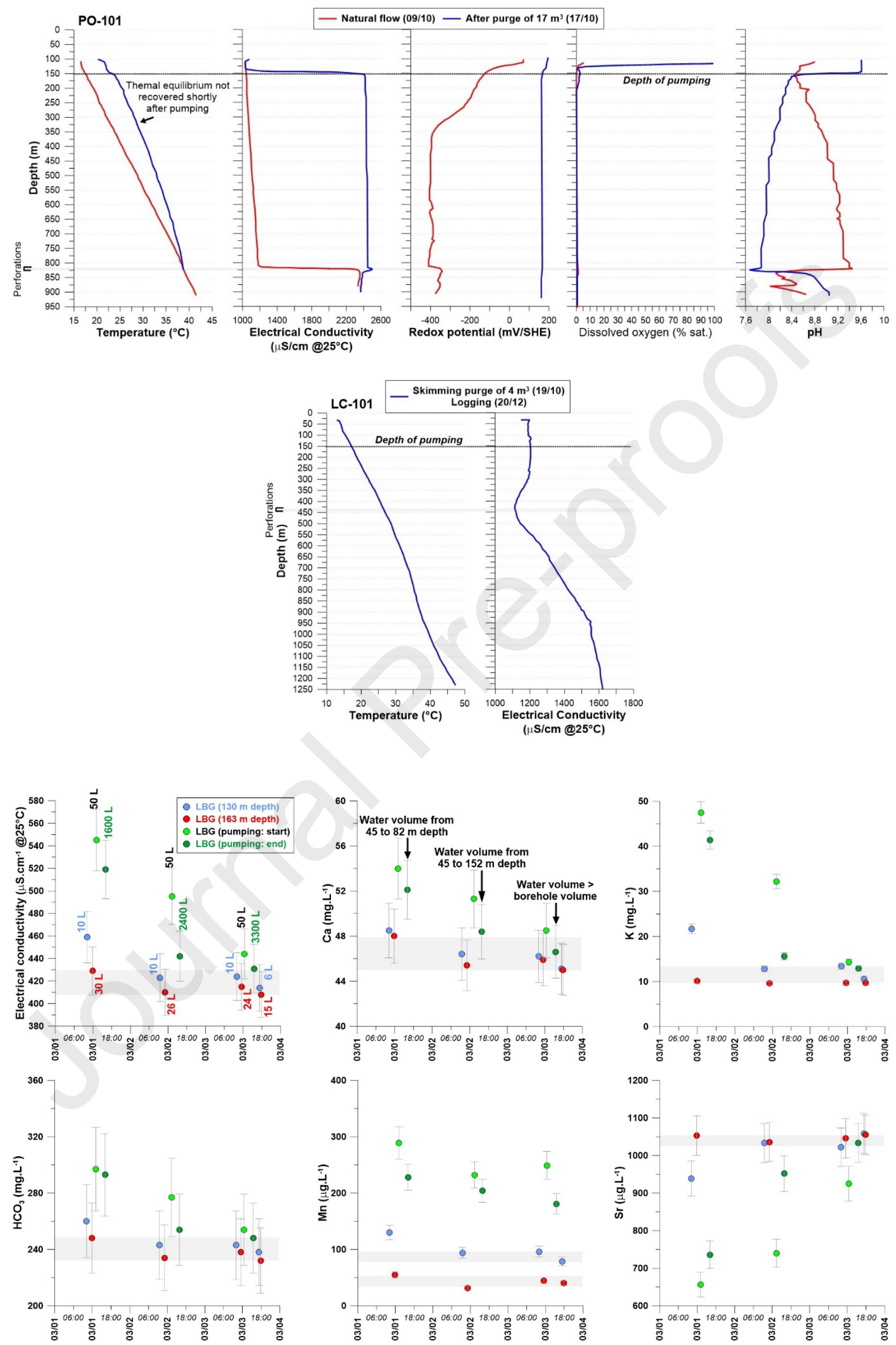


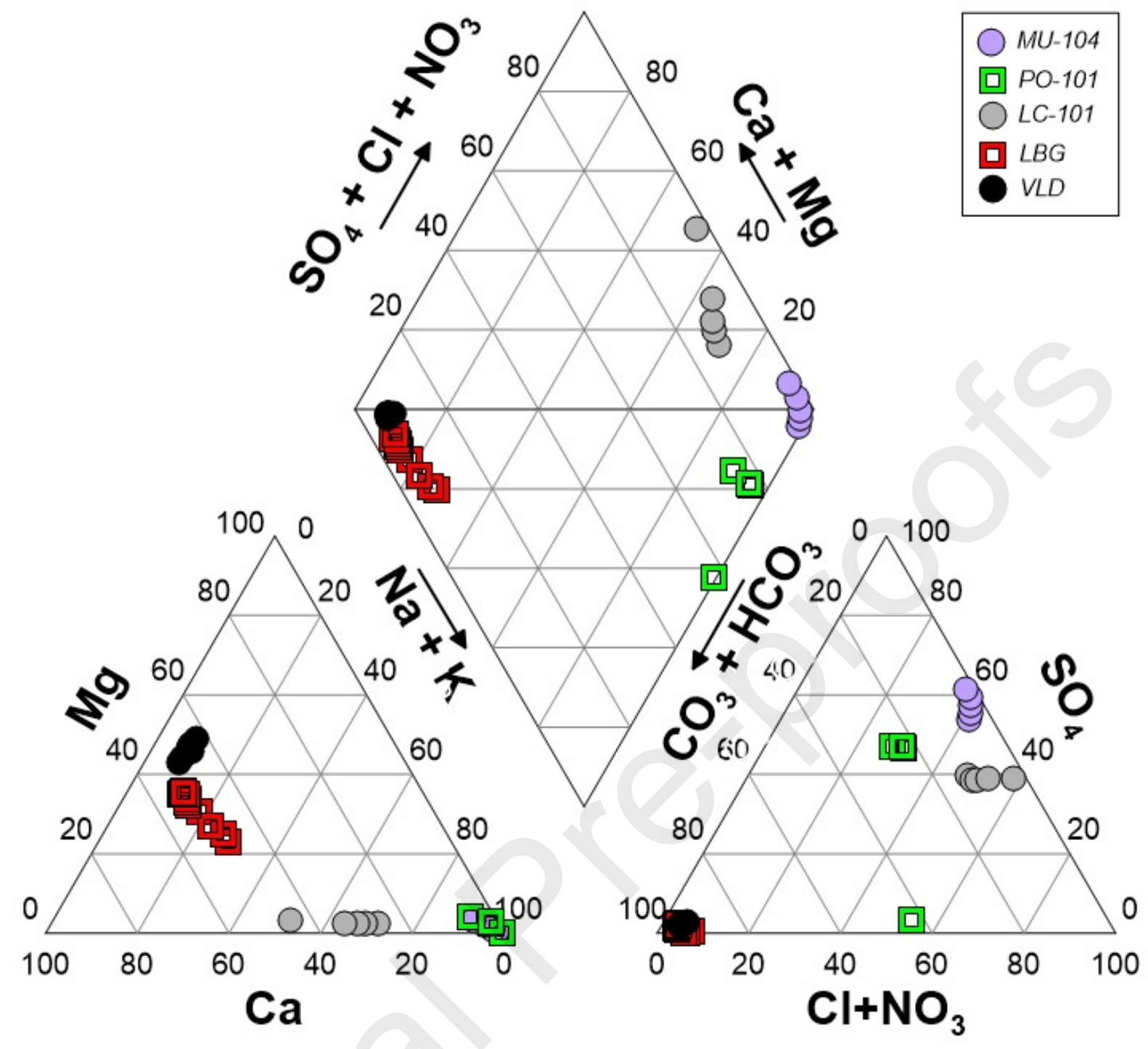



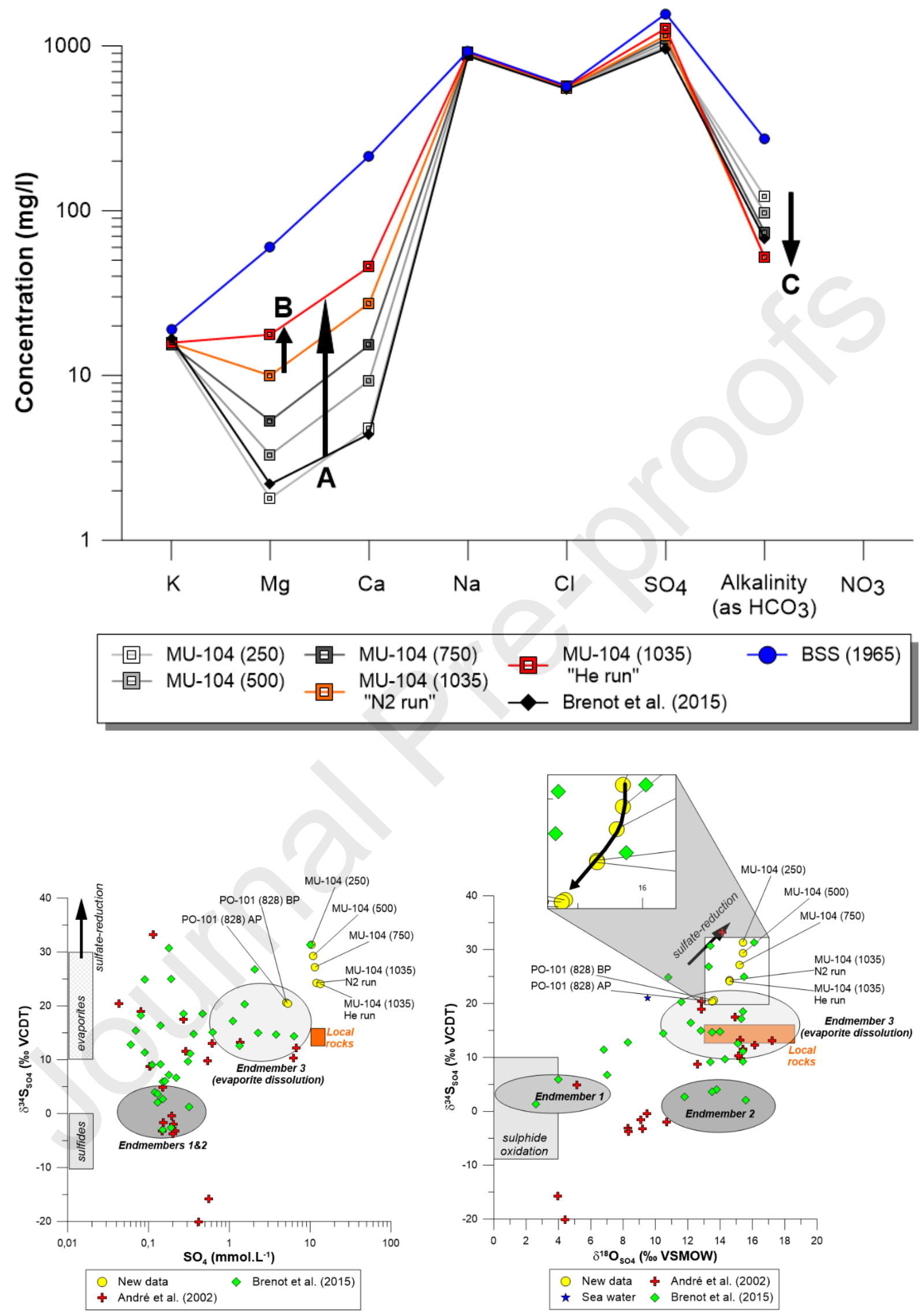